\title{
REE MOBILITY AND TETRAD EFFECTS IN BAUXITES: AN EXAMPLE FROM THE KANISHEETEH DEPOSIT, NW IRAN
}

\author{
Ali ABEDINI ${ }^{1)}$ *, Mansour REZAEI AZIZI ${ }^{1)}$ and Ali Asghar CALAGARI ${ }^{2)}$ \\ 1) Department of Geology, Faculty of Sciences, Urmia University, 5756151818, Urmia, Iran \\ 2) Department of Earth Sciences, Faculty of Natural Sciences, University of Tabriz, 5166616471, Tabriz, Iran \\ *Corresponding author's e-mail: abedini2020@yahoo.com and a.abedini@urmia.ac.ir
}

\begin{tabular}{l} 
ARTICLE INFO \\
\hline Article history: \\
Received 17 October 2018 \\
Accepted 3 January 2019 \\
Available online 15 January 2019 \\
\hline
\end{tabular}

\section{Keywords:}

REE

Mobility

Tetrad-effect

Bauxite

Kanisheeteh

Iran

\begin{abstract}
The Kanisheeteh bauxite deposit (NW Iran) is located on the Irano-Himalaya karst bauxite belt and was developed as stratiform horizon along the contact of the Permian and Triassic Formations. Based on absolute weathering index (AWI), HREE were leached out, whereas LREE suffered both leaching and fixation during bauxitization. The non-CHARAC characteristic of Y/Ho ratios can be attributed to geochemically known phenomenon as the "tetrad effect". The simultaneous convex and concave curves of the tetrad effect were observed in the chondritenormalized REE patterns of the bauxite ores. The correlation between the sizes of $\mathrm{T}_{4}$ and AWI\% values revealed two separate populations. The first one is characterized by a wide variation in sizes of $\mathrm{T}_{4}$ and very narrow AWI\% values, and is thought to be related to acidic zone of the profile. In contrast, the second one is marked by a narrow variation in sizes of $\mathrm{T}_{4}$ and wide variation in AWI\% values, and is conceived to be affiliated to alkaline zone of the profile. In this research, the tetrad effect proved to be capable of clarifying the geochemical characteristics of the deposit and can be applied as a good geochemical index to investigate the prevailed paleoconditions of depositional environments.
\end{abstract}

\section{INTRODUCTION}

Rare earth elements (REEs) have been used as a good and beneficial tool for investigation of geochemical processes during development and evolution of wide range of deposits in different environments (Chen and Zhao, 1997; Censi et al., 2007; Karadağ et al., 2009; Hannigan et al., 2010; Mongelli et al., 2016; Abedini et al., 2018a,b; Rezaei Azizi et al., 2018a,b). This coherent group of elements from $\mathrm{La}$ to $\mathrm{Lu}$ with atomic number from 57 to 71 displays very similar behavior due to their very similar ionic charge and radius. Except Ce (III and IV) and Eu (II and III), the rest of REEs in this group are characterized by trivalent oxidation state (Henderson, 1984). However, REE fractionations and redistributions have been reported from various bauxite deposits due to evolution of geochemical systems in various mechanisms and conditions such as mobilization of REE, supergene processes, surficial weathering, diagenetic processes, presence of REEbearing mineral phases, $\mathrm{pH}$ of solutions and/or depositional environment, and existence of organic and/or non-organic complexing ligands (Mondillo et al., 2011; Abedini and Calagari, 2013; Mongelli et al., 2014, 2016, 2017; Liu et al., 2016; Buccione et al., 2016; Hou et al., 2017; Khosravi et al., 2017; Long et al., 2017; Radusinovic et al., 2017; Torró et al., 2017; Yuste et al., 2017; Chen et al., 2018). Generally, these factors can widely affect the mobilization and fixation of REE in the mineral phases of the bauxite ores.

The normalized REE distribution patterns generally display very smooth curves because of their gradual decrease in ionic radius. Nevertheless, some irregular shapes in the normalized REE curves can be observed owing to the lanthanide tetrad effect (LTE) (Censi et al., 2007; Rezaei Azizi et al., 2017; Abedini et al., 2018b,c). The LTE as a geochemical feature brings about four separate groups of lanthanides in the normalized REE distribution patterns. The separated groups correspond to the one-fourth, half, threefourth, and filled of $4 f$ orbital in the lanthanides (Jahn et al., 2001). Therefore, these tetrads are labeled as first, second, third, and fourth tetrads corresponding to La-Nd, Pm-Gd, Gd-Ho, and Er-Lu, respectively. In fact, Gd is the only lanthanide element which takes part both in the second and third tetrads. The occurrence of such irregular patterns was reported initially from aqueous systems by using different terms such as 'kinked effect', 'zigzag effect', 'tetrad effect', and 'double-double effect' (Fidelis and Siekierski, 1966; Peppard et al., 1969). Ionic radius, electric charge, $\mathrm{pH}$, surficial absorption, mineral phases and stability of REE-complex are believed to be the main chemical parameters controlling the REE distributions in geological environments (Sasmaz et al., 2018). McLennan (1994) declared that the 


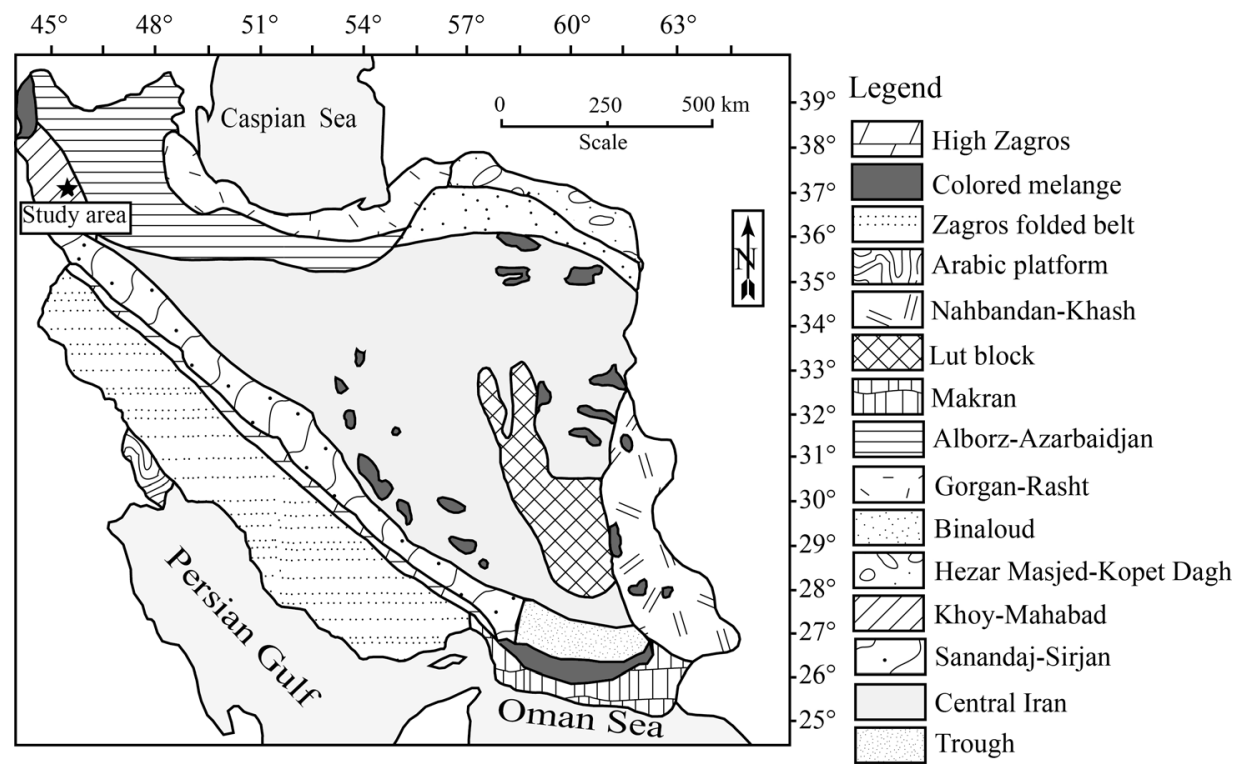

Fig. 1 Simplified geologic map displaying the structural zones of Iran (Nabavi, 1976). Location of the studied district is also shown in this figure.

lanthanide effect (LTE) or double-double feature (Masuda and Ikeuchi, 1978) is tetrad one of the factors which controls the REE distribution and affects their behavior. Despite controversy on the origin of this phenomenon by some researchers (McLennan, 1994; Nakamura et al., 2007), the LTE has been widely applied as a new and good geochemical indicator to assess the geochemical processes involved during bauxite formation (Akagi et al., 1993; Broska et al., 2006; Chu et al., 2009; Cunha et al., 2012; Abedini et al., 2017; Rezaei Azizi et al., 2017; Abedini et al., 2018a).

Studies showed that three different forms of tetrad effect usually occur in the normalized REE distribution patterns. The first form has a concave or $\mathrm{W}$-shaped curve which is mostly observed in the lowtemperature geological environments such as waters, limestone, marine sediments, and phosphorite (Masuda and Ikeuchi, 1978; Mazumdar et al., 2003; Yamamoto et al., 2004; Peretyazhko and Savina, 2010; Feng et al., 2014; Abedini et al., 2017). The second form of tetrad effect is characterized by a convex or M-shaped curve in their normalized REE distribution patterns indicating magmatic origin (e.g., granite) and associated evolved systems such as hydrothermal ore and gangue (e.g., fluorite) minerals (Kawabe, 1995; Haapala and Lukkari, 2005; Nardi et al., 2012; Cao et al., 2013; Lee et al., 2013; Rezaei Azizi et al. 2017). Finally, in the third form has both convex and concave (M- and $\mathrm{W}$-shaped) curves which are commonly observed in natural glasses, phosphatic shale as well as in uranium, fluorine, and aluminum (bauxite) deposits (Takahashi et al., 2002; Minuzzi et al., 2008; Zhao et al., 2010; Rezaei Azizi et al., 2017; Abedini et al., 2017; Abedini et al., 2018b). The tetrad effect phenomenon can be used as a good geochemical indicator to assess various geological environments (Akagi et al., 1993; McLennan, 1994; Bau, 1996). However, the relationship between the calculated values of the tetrad effect and some geochemical factors such as $\mathrm{Y} / \mathrm{Ho}$ ratio has not been investigated. Previous study indicates that LTE as a geochemical indicator can be used to assess the geochemical processes during buxitization and interpretation of REE distribution in this type of deposits (Abedini et al., 2018a).

Many bauxite deposits in Iran have located on the Irano-Himalaya karst bauxite belt and were developed during Permian-Cretaceous periods (Abedini and Calagari, 2014). The Kanisheeteh bauxite deposit is located in $\sim 19 \mathrm{~km}$ east of Bukan city, West-Azarbaidjan province, NW Iran. The geology, mineralogy, petrography and major element geochemistry of this deposit have been evaluated in detail by Calagari and Abedini (2007). The main aim of this study is mostly to consider the LTE and its possible source, the causes of fractionation between Y-Ho and Sm-Nd, the behavior of rare earth elements, and the $\mathrm{Ce}$ and Eu anomalies in the selected bauxite profile. Additionally, the correlation between the calculated values of the tetrad effect with aforementioned geochemical factors will be also discussed.

\section{GEOLOGICAL BACKGROUND AND PREVIOUS WORKS}

Previous studies indicate that most of Iranian bauxite deposits including the Kanisheeteh are a part of the Irano-Himalaya karst bauxite belt (Abedini and Calagari, 2014). Most of these bauxite deposits were likely formed during Permian to Jurassic periods (Calagari and Abedini, 2007). Detailed geological studies were carried out about a decade ago in this district by Calagari and Abedini (2007). 


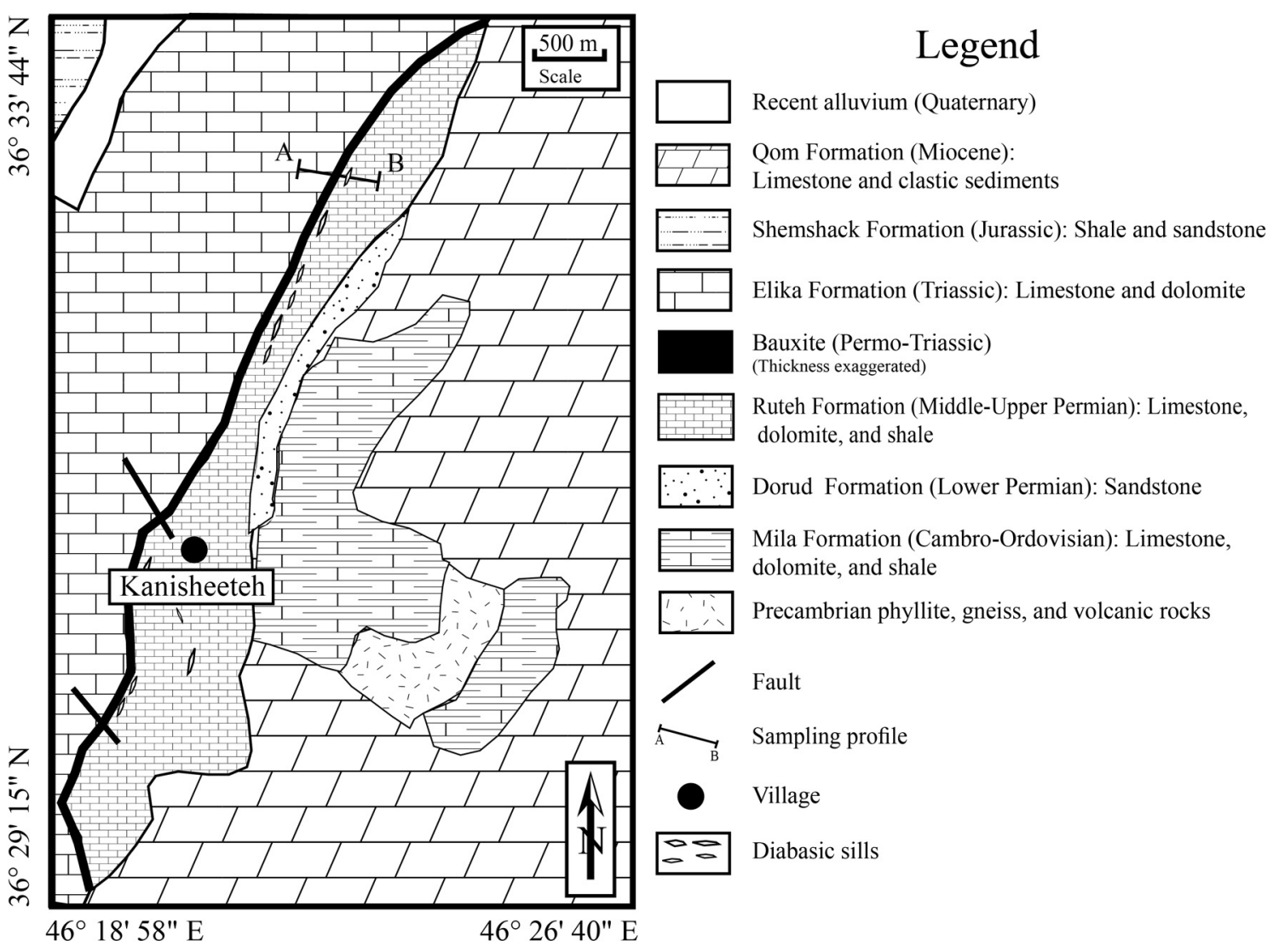

Fig. 2 Simplified geological map of the district (modified after Abedini and Calagari, 2014) illustrating the lithologic units, the location of the bauxite horizon, and the position of sampling profile.

According to the structural map of Iran (Nabavi, 1976), the Kanisheeteh bauxite deposit is a part of the Sanandaj-Sirjan metamorphic belt (Figure 1). Stratigraphically, the litholigic units cropping out in this district can be summarized from the oldest to the youngest as follow (Figure 2): (1) phyllite, gneiss, and volcanic eruptions of Precambrian age, (2) limestone, dolomite, and shale known as Mila Formation of Cambro-Ordovisian age, (3) sandstone known as Dorud Formation of lower Permian age, (4) limestone, dolomite, and shale known as Ruteh Formation of middle-upper Permian age, (5) bauxite horizon of Permo-Triassic age, (6) limestone and dolomite (Elika Formation) of Triassic age, (7) shale and sandstone (Shemshak Formation) of Jurassic age, (8) limestone and clastic sediments (Qom Formation) of Miocene age, and (9) recent alluvium of Quaternary age. Field observations revealed that some diabasic rocks occurring as sills and irregular patches within the lower Permian carbonates acted as plausible parent rocks (Calagari and Abedini, 2007). The bauxite horizon in this district has a NE-SW trending with about $8 \mathrm{~km}$ long and dips $35-90^{\circ} \mathrm{NW}$. This horizon shows variable thickness ( 8 to $28 \mathrm{~m}$ ) and lies along the boundary of late Permian (carbonates, shale) and Triassic (carbonates) units. The bauxite ores in this horizon are characterized by different colors like greenish cream, red, brownish red and dark red. Thus, based on the colors and textural specifications, the studied bauxite ores were divided into the following subgroups (Fig. 3): (1) dark red bauxite (DRB), (2) red bauxite (RB), (3) brownish red bauxite (BRB), (4) greenish cream bauxite (GCB), and finally (5) yellow bauxite (YB). Previous studies (Calagari and Abedini, 2007) indicated that most common mineral phases in this horizon were diaspore, hematite, kaolinite, nacrite, chlorite, pyrophyllite, quartz, muscovite, rutile, calcite, and magnesio-sidero-riebeckite. Furthermore, petrographic studies indicate that YB and GCB parts of the horizon are characterized by pressure shadow structures, while the $\mathrm{BRB}, \mathrm{RB}$, and DRB parts are generally marked by nodular, panidiomorphic-granular, ooidic, and pseudo-breccia textures.

\section{METHOD OF INVESTIGATION}

For chemical analysis thirty ore samples (with $0.5 \mathrm{~m}$ interval) from the bauxite profile (Figure 2) and three rock samples from diabase unit in the studied district were collected (Fig. 3). The chemical analyses (for 33 samples) were performed at the ACME Analytical Laboratories Ltd. in Vancouver, Canada. Trace elements including REE were analyzed by inductively coupled plasma-mass spectrometry (ICP- 


\section{Stratigraphic column}

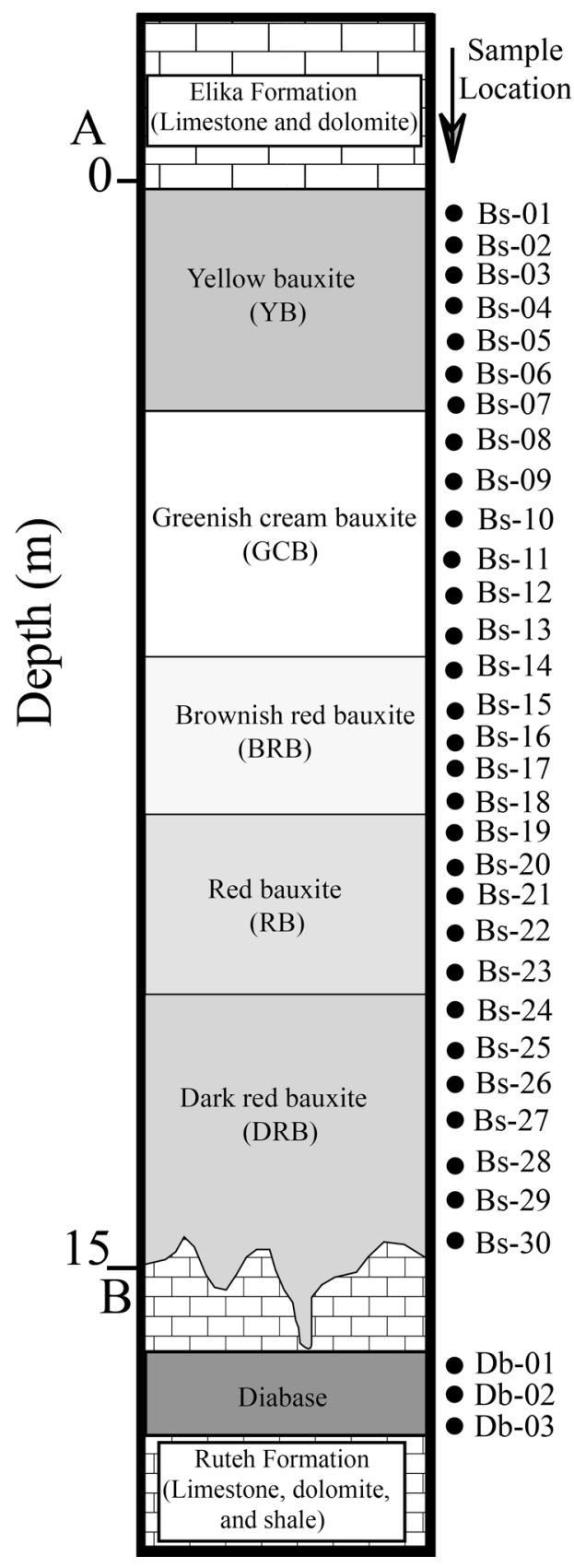

Fig. 3 Stratigraphic column of the bauxite horizon and position of the collected samples across this horizon. Location of sampling profile is shown in Figure 2.

MS) method. During analytic processes quality controls were subjected to the same center with blanks, duplicates, and standard materials (STD SO18) based on CQ report, certificate of analysis, detection limits (DT), and accuracy. About $0.2 \mathrm{gr}$ of each sample was carefully weighed, and then was treated by a lithium metaborate/tetraborate fusion and diluted in nitric acid as a digestion agent. These solutions were digested in hot Aqua Regia to be analyzed by ICP-MS method. Detection limits for elements are as follows: (1) for $\mathrm{Y}, \mathrm{La}$, and $\mathrm{Ce}$ is $0.5 \mathrm{ppm}$; (2) for $\mathrm{Nd}$, and $\mathrm{Lu}$ is $0.1 \mathrm{ppm}$; (3) for $\mathrm{Tb}$, $\mathrm{Ho}$, and $\mathrm{Tm}$ is $0.01 \mathrm{ppm}$; (4) for $\mathrm{Zr}$ is $2 \mathrm{ppm}$; and (5) for $\mathrm{Pr}, \mathrm{Sm} \mathrm{Eu}, \mathrm{Er}$, and $\mathrm{Yb}$ is $0.03 \mathrm{ppm}$. Furthermore, all the computations and plots were carried out by using MATLAB R2016b computer software.

\section{RESULTS \\ 4.1. REE, Y, AND ZR CONCENTRATIONS IN THE PROFILE}

Table 1 shows the concentration values of $\mathrm{Y}, \mathrm{Zr}$, and REE in the bauxite samples of the studied profile. According to this table, the $\mathrm{Y}$ concentration values vary within the range of 26.1-32.6 ppm. The inverse trend is observed in the $\mathrm{Zr}$ concentrations which vary from $220.9 \mathrm{ppm}$ to $289.5 \mathrm{ppm}$.

The $\sum$ REE values of the bauxite samples are within the range of 337.61-792.56 ppm (see Table 2). The LREE and HREE values of the bauxite samples vary from $318.55 \mathrm{ppm}$ to $732 \mathrm{ppm}$ and from $19.06 \mathrm{ppm}$ to $60.56 \mathrm{ppm}$, respectively (see Table 2). The (LREE/HREE) $)_{\mathrm{N}}, \mathrm{Y} / \mathrm{Ho}$, and $\mathrm{Sm} / \mathrm{Nd}$ ratios of the bauxite samples range from 4.8 to 6.66 and from 14.49 to 25.75 (average of 21.71), and from 0.15 to 0.27 , respectively (see Table 2 ).

\subsection{CE AND EU ANOMALIES}

To calculate the $\mathrm{Ce} / \mathrm{Ce}^{*}$ and $\mathrm{Eu} / \mathrm{Eu}^{*}$ values of the studied samples the following equations proposed by Bau and Dulsky (1996) and Monecke et al. (2000) were applied:

$$
\begin{aligned}
& \mathrm{Eu} / \mathrm{Eu}^{*}=\mathrm{Eu}_{\mathrm{N}} /\left[(\mathrm{Sm} \times \mathrm{Gd})^{0.5}\right] \\
& \mathrm{Ce} / \mathrm{Ce}^{*}=\mathrm{Ce}_{\mathrm{N}} /\left[(\mathrm{La} \times \mathrm{Pr})^{0.5}\right]
\end{aligned}
$$

In these equations, $\mathrm{N}$ refers to chondrite values proposed by Anders and Grevesse (1989). Based on the computed results (see Table 2), the values of $\mathrm{Ce} / \mathrm{Ce}^{*}$ in the bauxite samples vary from 0.92 to 2.73 . Similarly, the $\mathrm{Eu} / \mathrm{Eu}^{*}$ values in the diabase and bauxite samples lie within the range of 0.7-0.89 and $0.49-0.81$, respectively.

\section{DISCUSSION}

\subsection{REE VARIATION IN THE PROFILE}

The variations of rare earth elements along the studied profile of the bauxite horizon are illustrated in Figure 4 . The $\sum$ REE concentration increases gradually from the top to the bottom of the horizon (Figure 4a). The values for first $\left(\mathrm{RET}_{1}\right)$, second $\left(\mathrm{RET}_{2}\right)$, third $\left(\mathrm{RET}_{3}\right)$, and fourth $\left(\mathrm{RET}_{4}\right)$ tetrads of REE (Table 2) are illustrated in Figure 4b, Figure 4c, Figure 4d, and Figure $4 \mathrm{e}$, respectively. As illustrated in these figures, the distribution of total REE and REE of individual tetrads display similar trends from the top of the bauxite horizon to $\sim 6.5 \mathrm{~m}$ (YB and GCB) and different trend as REE concentrations increase from $6.5 \mathrm{~m}$ toward the bottom (BRB, RB, and $\mathrm{DRB})$ of the 
Table 1 Concentration values of REE, $\mathrm{Zr}$ and Y (in ppm) in the bauxite ore samples of the studied profile. The detection limits for each element are also shown.

\begin{tabular}{|c|c|c|c|c|c|c|c|c|c|c|c|c|c|c|c|c|}
\hline & $\begin{array}{l}\text { Detection } \\
\text { Limit }\end{array}$ & Bs-1 & Bs-2 & Bs-3 & Bs-4 & Bs-5 & Bs-6 & Bs-7 & Bs-8 & Bs-9 & Bs-10 & Bs-11 & Bs-12 & Bs-13 & Bs-14 & Bs- 15 \\
\hline $\mathbf{Y}$ & 0.5 & 29.1 & 28.8 & 28.6 & 27.4 & 27.4 & 27.5 & 27.6 & 26.8 & 28.5 & 28.5 & 28.1 & 28.6 & 28.4 & 29.5 & 29.9 \\
\hline $\mathbf{Z r}$ & 2 & 280.4 & 274.5 & 266.5 & 257.4 & 255.6 & 251.3 & 252.3 & 251.3 & 258. & 250.1 & 243.5 & 247.1 & 242.3 & 251.3 & 239.6 \\
\hline La & 0.5 & 68.9 & 71.9 & 74.5 & 72.1 & 62.1 & 73.6 & 75.8 & 76.8 & 80.7 & 81.2 & 84.5 & 88.1 & 88.2 & 91.1 & 94.8 \\
\hline $\mathrm{Ce}$ & 0.5 & 169.8 & 173.7 & 199.5 & 211.3 & 195.1 & 243.6 & 251.2 & 299.8 & 299.5 & 211.3 & 305.4 & 335.4 & 298.5 & 311.2 & 278.5 \\
\hline $\operatorname{Pr}$ & 0.03 & 15.15 & 15.41 & 15.88 & 15.15 & 14.78 & 15.55 & 16.29 & 16.82 & 17.88 & 18.22 & 18.19 & 20.08 & 20.49 & 21.41 & 21.19 \\
\hline Nd & 0.1 & 53.2 & 54.1 & 55.7 & 51.1 & 51.4 & 55.6 & 51.1 & 60.1 & 64.5 & 65.4 & 70.8 & 74.1 & 74.5 & 79.4 & 77.1 \\
\hline Sm & 0.03 & 9.68 & 9.54 & 10.11 & 9.54 & 9.22 & 10.07 & 10.98 & 11.45 & 12.55 & 12.89 & 14.45 & 11.12 & 15.45 & 16.78 & 15.88 \\
\hline Eu & 0.03 & 1.82 & 1.83 & 1.82 & 1.77 & 1.71 & 1.83 & 1.99 & 2.06 & 2.26 & 2.36 & 2.65 & 2.77 & 2.82 & 3.04 & 2.94 \\
\hline Gd & 0.05 & 6.05 & 6.74 & 6.98 & 6.71 & 5.97 & 5.94 & 7.34 & 7.57 & 8.12 & 8.32 & 8.95 & 9.61 & 9.88 & 10.67 & 10.83 \\
\hline Tb & 0.01 & 1.02 & 1.04 & 1.06 & 1.01 & 1.04 & 1.06 & 1.13 & 1.15 & 1.26 & 1.24 & 1.96 & 1.43 & 1.44 & 1.58 & 1.59 \\
\hline Dy & 0.05 & 5.73 & 5.67 & 5.77 & 5.61 & 5.51 & 5.72 & 6.1 & 6.07 & 6.51 & 6.52 & 6.91 & 7.25 & 7.33 & 7.91 & 7.99 \\
\hline Но & 0.01 & 1.13 & 1.13 & 1.14 & 1.08 & 1.07 & 1.13 & 1.12 & 1.16 & 1.21 & 1.23 & 1.25 & 1.31 & 1.32 & 1.41 & 1.43 \\
\hline Er & 0.03 & 3.38 & 3.36 & 3.37 & 3.24 & 3.22 & 3.35 & 3.46 & 3.44 & 3.59 & 3.68 & 3.67 & 3.81 & 3.89 & 4.47 & 7.03 \\
\hline Tm & 0.01 & 0.53 & 0.54 & 0.55 & 0.51 & 0.53 & 0.54 & 0.55 & 0.58 & 0.59 & 0.59 & 0.62 & 0.63 & 0.61 & 0.64 & 0.66 \\
\hline Yb & 0.03 & 0.66 & 0.62 & 3.61 & 3.54 & 3.49 & 3.62 & 3.75 & 3.01 & 3.98 & 3.97 & 4.09 & 4.21 & 4.26 & 4.48 & 4.45 \\
\hline \multirow[t]{2}{*}{ Lu } & 0.01 & 0.56 & 0.55 & 0.55 & 0.56 & 0.54 & 0.51 & 0.56 & 0.58 & 0.62 & 0.62 & 0.64 & 0.65 & 0.64 & 0.69 & 0.67 \\
\hline & $\begin{array}{c}\text { Detection } \\
\text { Limit }\end{array}$ & Bs-16 & Bs-17 & Bs-18 & Bs-19 & Bs-20 & Bs-21 & Bs-22 & Bs-23 & Bs-24 & Bs- 25 & Bs-26 & Bs-27 & Bs-28 & Bs-29 & Bs-30 \\
\hline $\mathbf{Y}$ & 0.5 & 29.4 & 28.9 & 26.1 & 29.4 & 28.3 & 28.4 & 27.9 & 28.9 & 29.9 & 29.2 & 28.2 & 28.6 & 30.4 & 31.8 & 32.6 \\
\hline $\mathbf{Z r}$ & 2 & 224.1 & 220.9 & 289.5 & 261.1 & 259.1 & 264.2 & 239.6 & 238.4 & 255.9 & 231.5 & 265.9 & 247.5 & 242.3 & 261.5 & 249.8 \\
\hline La & 0.5 & 86.5 & 82.7 & 80.3 & 84.2 & 81.1 & 87.2 & 85.7 & 88.6 & 101.2 & 95.4 & 105.2 & 105 & 124.5 & 146.2 & 152.5 \\
\hline $\mathrm{Ce}$ & 0.5 & 273.5 & 265.4 & 445.6 & 292.3 & 442.1 & 296.3 & 461.1 & 282.1 & 342.5 & 236.1 & 305.1 & 383.2 & 315.4 & 291.3 & 312.3 \\
\hline $\operatorname{Pr}$ & 0.03 & 19.32 & 18.46 & 19.14 & 19.44 & 18.65 & 20.54 & 19.49 & 21.03 & 23.84 & 22.91 & 28.74 & 26.41 & 30.74 & 39.41 & 42.11 \\
\hline Nd & 0.1 & 69.4 & 68.4 & 70.3 & 71.1 & 69.4 & 75.3 & 71.1 & 79.1 & 87.2 & 85.4 & 110.1 & 101.2 & 115.4 & 155.5 & 171.1 \\
\hline Sm & 0.03 & 11.12 & 10.14 & 14.44 & 14.79 & 13.22 & 15.69 & 14.88 & 16.03 & 18.44 & 17.74 & 24.65 & 22.14 & 27.14 & 38.41 & 45.58 \\
\hline Eu & 0.03 & 2.62 & 2.54 & 2.01 & 2.72 & 2.56 & 2.92 & 2.68 & 2.05 & 3.22 & 3.13 & 4.31 & 4.11 & 5.01 & 7.09 & 8.41 \\
\hline Gd & 0.05 & 9.88 & 9.44 & 9.71 & 9.92 & 9.22 & 10.18 & 9.31 & 9.92 & 10.64 & 10.22 & 11.52 & 12.64 & 15.02 & 21.62 & 23.65 \\
\hline Tb & 0.01 & 1.47 & 1.41 & 1.47 & 1.51 & 1.42 & 1.54 & 1.48 & 1.51 & 1.65 & 1.56 & 1.02 & 1.97 & 2.31 & 3.61 & 3.73 \\
\hline Dy & 0.05 & 7.44 & 7.27 & 7.38 & 7.81 & 7.47 & 7.66 & 7.44 & 7.05 & 1.94 & 7.66 & 9.32 & 9.04 & 10.87 & 14.17 & 15.44 \\
\hline Но & 0.01 & 1.37 & 1.36 & 1.32 & 1.44 & 1.37 & 1.32 & 1.21 & 1.29 & 1.41 & 1.35 & 1.59 & 1.48 & 1.72 & 2.13 & 2.25 \\
\hline $\mathbf{E r}$ & 0.03 & 3.21 & 3.87 & 3.99 & 4.18 & 4.09 & 4.05 & 3.94 & 3.841 & 3.84 & 3.87 & 4.51 & 4.24 & 4.81 & 5.81 & 6.13 \\
\hline Tm & 0.01 & 0.62 & 0.63 & 0.66 & 0.68 & 0.69 & 0.66 & 0.67 & 0.66 & 0.71 & 0.64 & 0.77 & 0.74 & 0.83 & 1.04 & 1.11 \\
\hline Yb & 0.03 & 4.12 & 4.11 & 4.45 & 4.79 & 4.81 & 4.65 & 4.51 & 4.42 & 4.81 & 4.48 & 5.36 & 5.14 & 5.88 & 7.32 & 7.08 \\
\hline Lu & 0.01 & 0.64 & 0.63 & 0.71 & 0.73 & 0.74 & 0.73 & 0.71 & 0.67 & 0.74 & 0.68 & 0.81 & 0.78 & 0.86 & 1.07 & 1.17 \\
\hline
\end{tabular}


Table 2. The calculated geochemical parameters as well as the tetrad-effect sizes in the bauxite ores of the studied horizon.

\begin{tabular}{|c|c|c|c|c|c|c|c|c|c|c|c|c|c|c|c|}
\hline & Bs-1 & Bs-2 & Bs-3 & Bs-4 & Bs-5 & Bs-6 & Bs-7 & Bs- 8 & Bs-9 & Bs-10 & Bs-11 & Bs-12 & Bs-13 & Bs-14 & Bs- 15 \\
\hline $\mathrm{Eu} / \mathrm{Eu}^{*}$ & 0.72 & 0.69 & 0.66 & 0.67 & 0.70 & 0.72 & 0.67 & 0.67 & 0.68 & 0.69 & 0.71 & 0.81 & 0.69 & 0.69 & 0.68 \\
\hline $\mathrm{Ce} / \mathrm{Ce}^{*}$ & 1.26 & 1.25 & 1.39 & 1.53 & 1.54 & 1.73 & 1.71 & 2.00 & 1.89 & 1.32 & 1.87 & 1.91 & 1.68 & 1.69 & 1.49 \\
\hline $\mathrm{T}_{3}$ & 0.04 & 0.02 & 0.03 & 0.02 & 0.07 & 0.07 & 0.02 & 0.02 & 0.03 & 0.02 & 0.35 & 0.02 & 0.01 & 0.02 & 0.02 \\
\hline $\mathrm{T}_{4}$ & 0.58 & 0.59 & 0.03 & 0.01 & 0.03 & 0.06 & 0.02 & 0.15 & 0.03 & 0.02 & 0.04 & 0.03 & 0.01 & 0.05 & 0.22 \\
\hline LREE & 318.55 & 326.48 & 357.51 & 360.96 & 334.31 & 400.25 & 407.36 & 467.03 & 477.39 & 391.37 & 495.99 & 531.57 & 499.96 & 522.93 & 490.41 \\
\hline HREE & 19.06 & 19.65 & 23.03 & 22.26 & 21.37 & 21.87 & 24.01 & 23.56 & 25.88 & 26.17 & 28.09 & 28.90 & 29.37 & 31.85 & 34.65 \\
\hline$(\mathrm{LREE} / \mathrm{HREE})_{\mathrm{N}}$ & 5.55 & 5.58 & 5.31 & 5.44 & 5.14 & 5.87 & 5.60 & 6.18 & 5.91 & 5.27 & 5.47 & 5.92 & 5.77 & 5.59 & 5.05 \\
\hline $\mathrm{RET}_{1}$ & 307.05 & 315.11 & 345.58 & 349.65 & 323.38 & 388.35 & 394.39 & 453.52 & 462.58 & 376.12 & 478.89 & 517.68 & 481.69 & 503.11 & 471.59 \\
\hline $\mathrm{RET}_{2}$ & 17.55 & 18.11 & 18.91 & 18.02 & 16.90 & 17.84 & 20.31 & 21.08 & 22.93 & 23.57 & 26.05 & 23.50 & 28.15 & 30.49 & 29.65 \\
\hline $\mathrm{RET}_{3}$ & 13.93 & 14.58 & 14.95 & 14.41 & 13.59 & 13.85 & 15.69 & 15.95 & 17.10 & 17.31 & 19.07 & 19.60 & 19.97 & 21.57 & 21.84 \\
\hline $\mathrm{RET}_{4}$ & 5.13 & 5.07 & 8.08 & 7.85 & 7.78 & 8.02 & 8.32 & 7.61 & 8.78 & 8.86 & 9.02 & 9.30 & 9.40 & 10.28 & 12.81 \\
\hline Y/Ho & 25.75 & 25.49 & 25.09 & 25.37 & 25.61 & 24.34 & 24.64 & 23.10 & 23.55 & 23.17 & 22.48 & 21.83 & 21.52 & 20.92 & 20.91 \\
\hline \multirow[t]{2}{*}{$\mathrm{Sm} / \mathrm{Nd}$} & 0.18 & 0.18 & 0.18 & 0.19 & 0.18 & 0.18 & 0.21 & 0.19 & 0.19 & 0.20 & 0.20 & 0.15 & 0.21 & 0.21 & 0.21 \\
\hline & Bs-16 & Bs-17 & Bs-18 & Bs-19 & Bs-20 & Bs-21 & Bs-22 & Bs-23 & Bs-24 & Bs-25 & Bs-26 & Bs-27 & Bs-28 & Bs-29 & Bs-30 \\
\hline $\mathrm{Eu} / \mathrm{Eu}^{*}$ & 0.72 & 0.69 & 0.66 & 0.67 & 0.70 & 0.72 & 0.67 & 0.67 & 0.68 & 0.69 & 0.71 & 0.81 & 0.69 & 0.69 & 0.68 \\
\hline $\mathrm{Ce} / \mathrm{Ce}^{*}$ & 1.26 & 1.25 & 1.39 & 1.53 & 1.54 & 1.73 & 1.71 & 2.00 & 1.89 & 1.32 & 1.87 & 1.91 & 1.68 & 1.69 & 1.49 \\
\hline $\mathrm{T}_{3}$ & 0.04 & 0.02 & 0.03 & 0.02 & 0.07 & 0.07 & 0.02 & 0.02 & 0.03 & 0.02 & 0.35 & 0.02 & 0.01 & 0.02 & 0.02 \\
\hline $\mathrm{T}_{4}$ & 0.58 & 0.59 & 0.03 & 0.01 & 0.03 & 0.06 & 0.02 & 0.15 & 0.03 & 0.02 & 0.04 & 0.03 & 0.01 & 0.05 & 0.22 \\
\hline LREE & 462.46 & 447.64 & 631.79 & 484.55 & 627.03 & 497.95 & 654.95 & 488.91 & 576.40 & 460.68 & 578.10 & 642.06 & 618.19 & 677.91 & 732.00 \\
\hline HREE & 28.75 & 28.72 & 29.69 & 31.06 & 29.81 & 30.79 & 29.27 & 29.36 & 25.74 & 30.46 & 34.90 & 36.03 & 42.30 & 56.77 & 60.56 \\
\hline$(\mathrm{LREE} / \mathrm{HREE})_{\mathrm{N}}$ & 5.40 & 5.21 & 6.26 & 5.18 & 6.17 & 5.44 & 6.62 & 5.59 & 6.66 & 5.52 & 6.30 & 6.02 & 5.48 & 4.80 & 4.92 \\
\hline $\mathrm{RET}_{1}$ & 448.72 & 434.96 & 615.34 & 467.04 & 611.25 & 479.34 & 637.39 & 470.83 & 554.74 & 439.81 & 549.14 & 615.81 & 586.04 & 632.41 & 678.01 \\
\hline $\mathrm{RET}_{2}$ & 23.62 & 22.12 & 26.16 & 27.43 & 25.00 & 28.79 & 26.87 & 28.00 & 32.30 & 31.09 & 40.48 & 38.89 & 47.17 & 67.12 & 77.64 \\
\hline $\mathrm{RET}_{3}$ & 20.16 & 19.48 & 19.88 & 20.68 & 19.48 & 20.70 & 19.44 & 19.77 & 15.64 & 20.79 & 23.45 & 25.13 & 29.92 & 41.53 & 45.07 \\
\hline $\mathrm{RET}_{4}$ & 8.59 & 9.24 & 9.81 & 10.38 & 10.33 & 10.09 & 9.83 & 9.59 & 10.10 & 9.67 & 11.45 & 10.90 & 12.38 & 15.24 & 15.49 \\
\hline Y/Ho & 21.46 & 21.25 & 19.77 & 20.42 & 20.66 & 21.52 & 23.06 & 22.40 & 21.21 & 21.63 & 17.74 & 19.32 & 17.67 & 14.93 & 14.49 \\
\hline $\mathrm{Sm} / \mathrm{Nd}$ & 0.16 & 0.15 & 0.21 & 0.21 & 0.19 & 0.21 & 0.21 & 0.20 & 0.21 & 0.21 & 0.22 & 0.22 & 0.24 & 0.25 & 0.27 \\
\hline
\end{tabular}



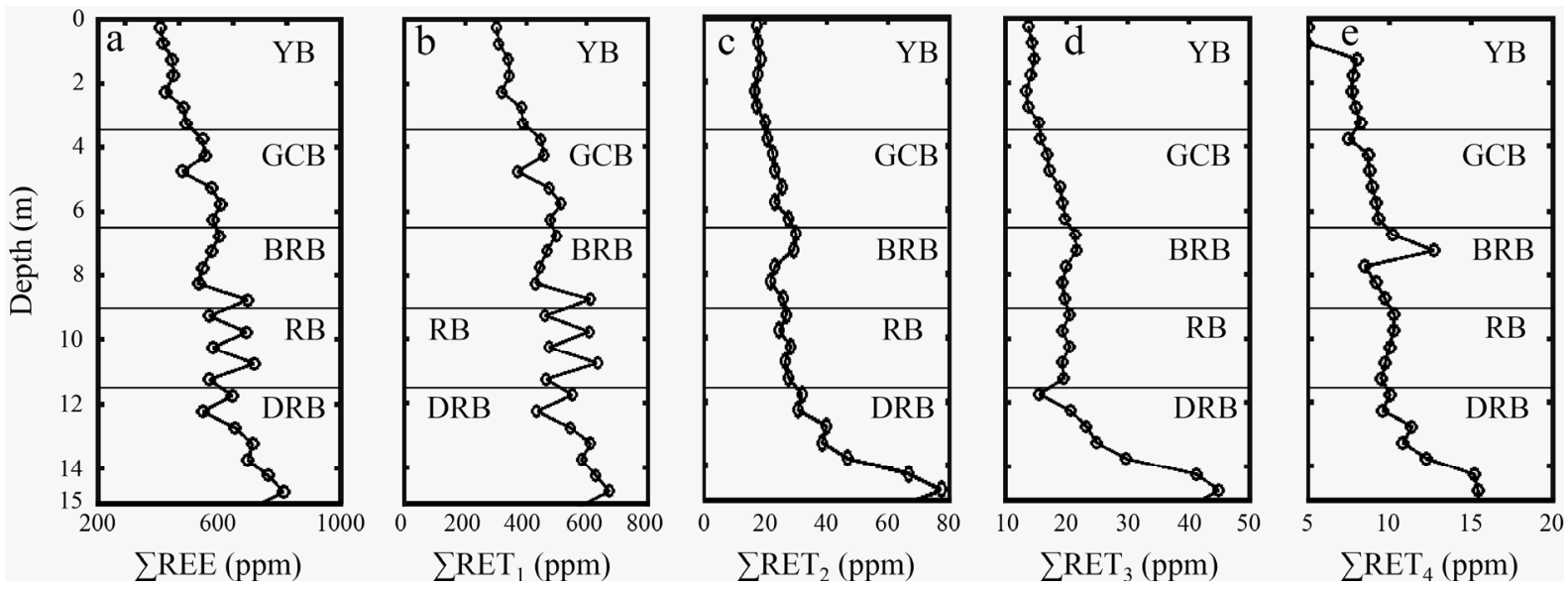

Fig. 4 Concentration variations of (a) REE, (b) La-Nd as first tetrad (RET 1 ), (c) Sm-Gd as second tetrad $\left(\mathrm{RET}_{2}\right),(\mathrm{d}) \mathrm{Tb}-\mathrm{Ho}$ as third tetrad $\left(\mathrm{RET}_{3}\right)$, and (e) Er-Lu as fourth tetrad $\left(\mathrm{RET}_{4}\right)$ with depth in the studied bauxite horizon.
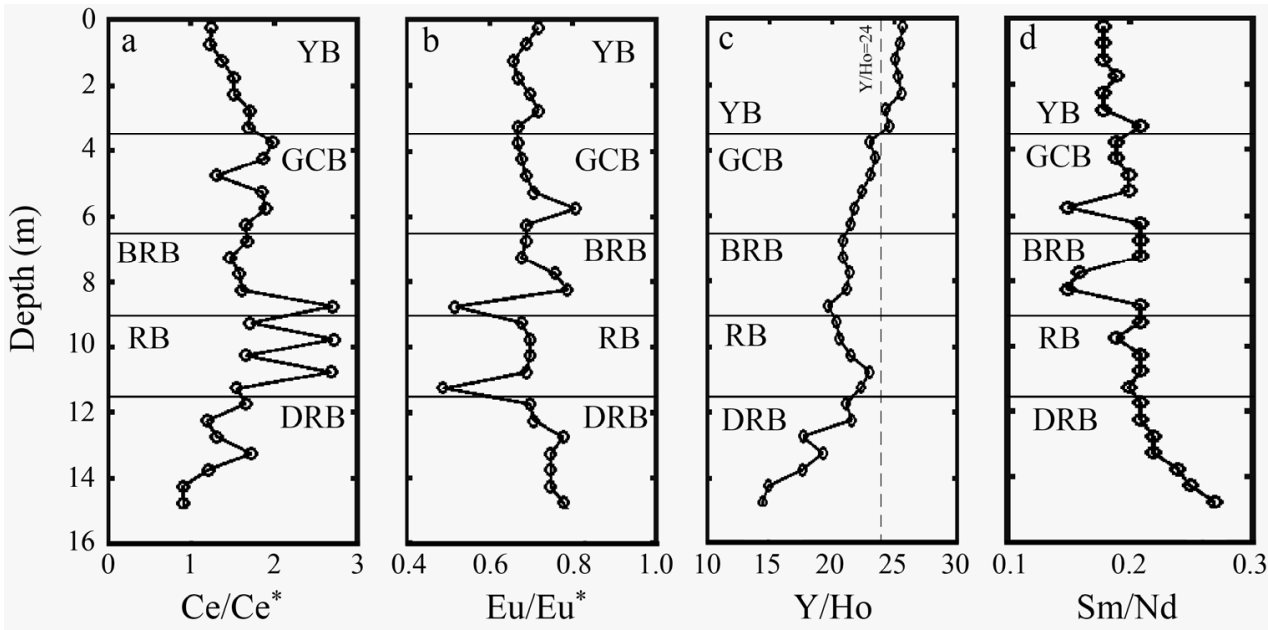

Fig. 5 Vertical variations of (a) $\mathrm{Ce} / \mathrm{Ce}^{*}$, (b) $\mathrm{Eu} / \mathrm{Eu}^{*}$, (c) $\mathrm{Y} / \mathrm{Ho}$ ratios, and (d) $\mathrm{Sm} / \mathrm{Nd}$ ratios with depth in the bauxite horizon. The chondritic value for Y/Ho ratio (24) is from Bau (1996).

horizon. These trends are probably owing to the $\mathrm{pH}$ increase of the solution responsible for bauxitization. This is quite consistent with the results of the previous studies conducted by Calagari and Abedini (2007). As shown in Figure 4e, fourth tetrads (Er to $\mathrm{Lu}$ ) are more sensitive to $\mathrm{pH}$ condition and can better reflect the paleo-redox conditions of the depositional environment. The concentration values of $\mathrm{RET}_{4}$ display a sharp decrease in samples Bs-15 and Bs-16 which may also be related to the $\mathrm{pH}$ changes of the solution during bauxitization processes. Therefore, it can be deduced that the upper part of the horizon (from the top to $\sim 6.5 \mathrm{~m}$ ) (YB and GCB) have likely been affected by low-pH solutions but, the lower part (from $6.5 \mathrm{~m}$ to the bottom) (BRB, RB, and DRB) have been possibly affected by relatively higher $\mathrm{pH}$ solutions.

The $\mathrm{Ce} / \mathrm{Ce}^{*}$ values in the studied profile (Figure 5a) gradually increase from the top to $\sim 6.5 \mathrm{~m}$ (YB and GCB), but fluctuate from $6.5 \mathrm{~m}$ to the bottom of the horizon (BRB, RB, and $\mathrm{DRB})$. The variable trends in $\mathrm{Ce} / \mathrm{Ce}^{*}$ values can be related to change in the redox conditions of the depositional environment, because $\mathrm{Ce}$ is strongly an oxide sensitive element (Hannigan et al., 2010). The increase in the oxygen fugacity of depositional environment causes trivalent $\mathrm{Ce}$ to be converted into tetravalent $\mathrm{Ce}$ which has higher charge and same ionic radius (Kraemer et al., 2016), and becomes less mobile relative to other trivalent rare earth elements (Constantopoulos, 1988). Therefore, oxidation conditions of an environment gives rise to an increase in positive $\mathrm{Ce}$ anomaly in the precipitant materials (Mongelli et al., 2014). Thus, it can be concluded that the upper part of the horizon (YB and GCB) in this district was likely deposited under higher oxygen fugacity condition due to the percolating oxic meteoric waters/solutions. These anomalies decrease in the lower parts of the horizon (BRB, RB, and DRB) due to the complexation of $\mathrm{Ce}^{4+}$ with carbonate ligands and hence its leaching during bauxitization processes (Karadağ et al., 2009).

Based on the SHAB theory proposed by Dai (1987), under low oxygen fugacity, some reduced species such as $\mathrm{CO}, \mathrm{CH}_{4}, \mathrm{~S}_{2} \mathrm{O}_{3}{ }^{2-}, \mathrm{S}^{2-}$, and $\mathrm{HS}^{-}$increase in aqueous system. In such an environment, $\mathrm{Eu}^{2+}$ 


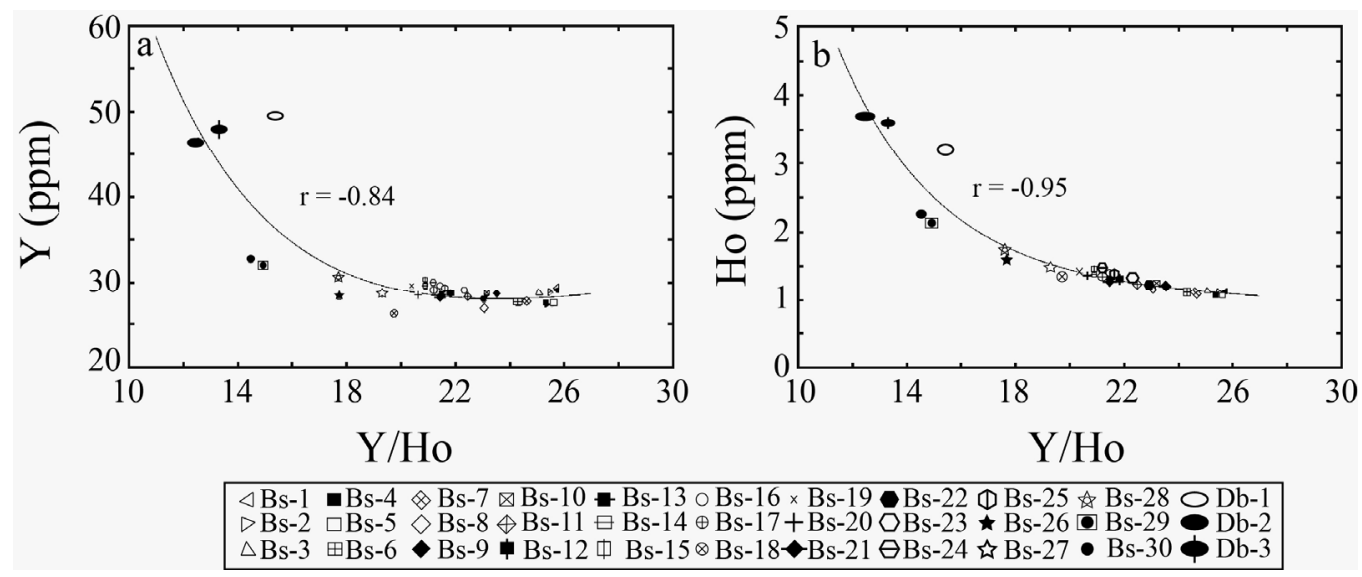

Fig. 6 Bivariate plot of Y/Ho ratios vs. (a) Y (ppm) and (b) Ho (ppm) values of the samples within the studied horizon.

commonly prevails and remains in solution as stable $\mathrm{Eu}^{2+}$-complex and hence is available for incorporation into $\mathrm{Eu}$ precipitates (positive anomaly). In contrast, under the higher oxygen fugacity, $\mathrm{Eu}^{3+}$ dominates in aqueous system and needs hard bases such as $\mathrm{OH}^{-}$, $\mathrm{SO}_{4}{ }^{2-}$, and $\mathrm{CO}_{3}{ }^{2-}$ (specially $\mathrm{OH}^{-}$) to become precipitated, consequently negative $\mathrm{Eu}$ anomaly is conceivable (Chen and Zhao, 1997). Furthermore, Abedini et al. (2016) suggested that strong negative $\mathrm{Eu}$ anomaly can be related to the higher $\mathrm{fO}_{2}$ and low $\mathrm{pH}$ of solutions. As Figure $5 \mathrm{~b}$ demonstrates, the $\mathrm{Eu}$ anomaly of the bauxite samples increases gradually from the top to the bottom of the bauxite horizon. This signifies that the studied horizon was likely formed by solutions experiencing low-pH and oxidizing conditions during deposition.

Y/Ho (Figure 5c) and $\mathrm{Sm} / \mathrm{Nd}$ (Figure $5 \mathrm{~d}$ ) ratios of the bauxite samples display opposite trends in the horizon. The $\mathrm{Sm} / \mathrm{Nd}$ values increases gradually from the top toward the bottom of the profile whereas, the $\mathrm{Y} / \mathrm{Ho}$ values decreases with depth. The Y/Ho values of the samples from the yellow bauxite (YB) are almost close to those of chondrite which vary from 24 to 34 (Bau, 1996). The $\mathrm{Y}$ and $\mathrm{Ho}$ as a geochemical pair with similar behavior can yield useful information about depositional conditions because their distribution in geochemical processes is controlled by their CHARAC (CHArge-RAdius Control) parameter (Bau, 1996). This means that variation of $\mathrm{Y} / \mathrm{Ho}$ ratio in geochemical processes reflects the prevailing physico-chemical conditions of depositional environment. Therefore, the nonCHARAC ratios and behavior of coherent elements such as $\mathrm{Y}$ and Ho can be interpreted by and/or attributed to tetrad effect feature in the geochemical processes (Abedini et al., 2017; Rezaei Azizi et al., 2017; Abedini et al., 2018b). The plots of Y/Ho ratios versus Y (Figure 6a) and Ho (Figure 6b) indicate a meaningful negative correlation as follows:

$\mathrm{Ho}=82.11 \times \exp (-0.2767 \times / \mathrm{Ho})+1.522 \times \exp (-0.015 \times \mathrm{Y} / \mathrm{Ho})$ $(r=-0.95$ with $95 \%$ confidence)

$\mathrm{Y}=456.6 \times \exp (-0.2243 \times \mathrm{Y} / \mathrm{Ho})+16.12 \times \exp (0.0199 \times \mathrm{Y} / \mathrm{Ho})$

( $r=-0.84$ with $95 \%$ confidence)

$\mathrm{Y} / \mathrm{Ho}$ ratio exhibits an increasing trend with decreasing $\mathrm{Y}$ and Ho concentrations in all of the samples. The correlation between $\mathrm{Ho}$ and $\mathrm{Y} / \mathrm{Ho}$ is equal to -0.95 which is higher than that between $\mathrm{Y}$ and $\mathrm{Y} / \mathrm{Ho}(\mathrm{r}=-0.84)$ indicating $\mathrm{Y} / \mathrm{Ho}$ ratios of the studied samples were likely controlled merely by increase of Ho rather than $\mathrm{Y}$. This continuous decrease in $\mathrm{Y} / \mathrm{Ho}$ ratio from the top to the bottom of the horizon may be as the result of gradual $\mathrm{pH}$ increase of the solutions percolating from the upper part of the horizon toward the carbonate bedrocks.

\subsection{TETRAD EFFECT}

In order to calculate the deviation of irregular curves from normal and smoothed forms in the chondrite-normalized REE distribution patterns (due to the LTE), some quantification methods have been proposed (Irber, 1999; Monecke et al., 2002). The following equation (5) was applied to compute the size of tetrad effect in each tetrad group of REE:

$T_{i}=\sqrt{\left.\frac{1}{2} *\left[\frac{X_{B i}}{\sqrt[3]{\left(X_{A i}^{2} \times X_{D i}\right)}}-1\right]^{2}+\left[\frac{X_{C i}}{\sqrt[3]{\left(X_{D i}^{2} \times X_{A i}\right)}}-1\right]^{2}\right)}$

In this equation the concentration of elements in each tetrad is shown by $\mathrm{X}$. meanwhile, the A, B, C, and $\mathrm{D}$ indicate first, second, third, and fourth elements in each individual tetrad group, respectively. Moreover, i equals to $1,2,3$, and 4 which indicating the first, second, third, and fourth tetrad, respectively. The tetrad effect is regarded to be significant for $T_{i}$ greater than zero. This means that $T_{i}$ equal to zero display no deviation between two middle elements of 


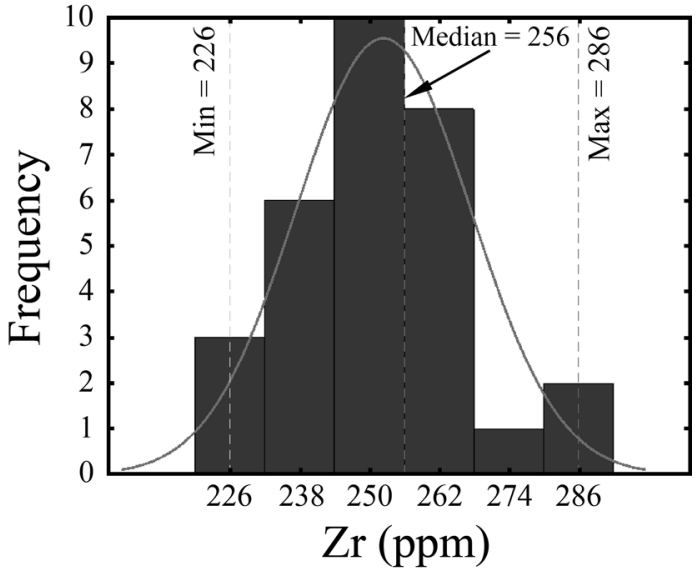

Fig. 7 Diagram of frequency distribution for $\mathrm{Zr}$ concentration values in the studied bauxite ore samples. The min, max, median and standard deviation values are 226, 286, 256, and 22.45 , respectively.

individual tetrads and therefore all four elements are in the straight line connecting the first and fourth elements.

In the calculation processes $T_{1}$ will not be computed if Ce behaves anomalously (Monecke et al., 2002). $T_{2}$ also cannot be calculated due to lack of Pm in natural geological systems (McLennan, 1994). Table 2 shows the computed values of $T_{3}$ and $T_{4}$ tetrad effect in the bauxite samples of the studied district. Based on the computed results, the sizes of $\mathrm{T}_{3}$ and $\mathrm{T}_{4}$ tetrad effect of the horizon vary within the range of $0.01-0.54$ and $0.01-0.59$, respectively.

\subsection{COMPUTATION OF MASS CHANGE OF REE DURING BAUXITIZATION}

Many computational methods have been proposed for calculation of mass changes of elements during geochemical processes such as alteration and weathering based on volume factor (Gresens, 1967), immobile element (Brimhall and Dietrich, 1987; MacLean and Kranidiotis, 1987), Absolute Weathering Index (AWI) (Nesbitt, 1979), isocon (Grant, 1986), mobility index (Ng et al., 2001), variation in ratios (Nesbitt and Markovics, 1997), chemical depletion fraction or CDF (Riebe et al., 2003), and immobile plateau (Gong et al., 2011). Generally, calculations of mass transfer in these methods are similar. Selection of a proper immobile element for implementing mass transfer is an important parameter. Previous studies have shown that some elements such as $\mathrm{Al}, \mathrm{Ti}, \mathrm{Nb}, \mathrm{Ta}, \mathrm{Zr}$, Hf, and Th (MacLean et al., 1997; Braun et al., 1998; Duzgoren-Aydin et al., 2002; Little and Aeolus, 2006; Ma et al., 2007; Hastie et al., 2008; Ndjigui et al., 2008; Gong et al., 2011) generally have semi-mobile or immobile behavior during geochemical processes such as weathering and/or alteration of rocks. These elements are characterized by very low dissolution rate due to their high field strength (HFS) during geochemical processes (Little and Aeolus, 2006). As illustrated in Figure. 7, $\mathrm{Zr}$ displays the slightest concentration variations among these elements in the studied profile (with median of $256 \mathrm{ppm}$ and standard deviation of 22.45 ) which is about $8.77 \%$. The previous studies conducted by Calagari and Abedini (2007) on this horizon revealed that the diabasic rocks were the plausible precursor for the bauxite ores. Considering the diabase as precursor, the degree of mobility for elements in the studied profile was calculated by following equation proposed by Nesbitt (1979):

AWI $(\%)=\left[\left(\mathrm{C}_{\text {Bauxite }} / \mathrm{Zr}_{\text {Bauxite }}\right) /\left(\mathrm{C}_{\text {Parent }} / \mathrm{Zr}_{\text {Parent }}\right)-1\right] \times 100$

In this equation $\mathrm{C}$ refers to a selected element and AWI will be in \%. Duzgoren-Aydin et al. (2002) declared that equation (6) can be used with high accuracy for rocks experienced severe weathering processes. The computed values of AWI (\%) in the bauxite samples (Table 2) are illustrated in Figure 8. As shown in this figure, rare earth elements of the first $\left(\mathrm{RET}_{1}\right)$ and second $\left(\mathrm{RET}_{2}\right)$ tetrads suffered depletion in the upper part of the profile and became enriched in the lower part. Among REE, Ce, Pr, Nd, and Sm show a slight depletion on the YB part of the horizon and this trend turns to enrichment in the other parts of the horizon. $\mathrm{Eu}, \mathrm{Gd}$, and $\mathrm{Tb}$ were depleted in most part of the horizon and became enriched only in DRB part of the horizon. Most of the third and fourth tetrad groups including Dy, Ho, Er, Tm, Yb, and Lu were depleted during bauxitization processes of the parent rocks. The depletion of REE in the upper part and their enrichment in the lower part of the profile are affiliated with leaching processes exerted by descending solutions.

\subsection{FACTORS CONTROLLING THE BEHAVIOR OF REE}

The $\sum$ LREE (La-Eu) values in the studied profile increases from the top to the bottom of the horizon (Figure 9a). This implies that these elements were likely leached from the upper parts (YB and GCB) of the profile and precipitated in the lower parts (BRB, RB, and DRB). The SHREE (Gd-Lu) and $\sum$ LREE values (Figure 9b) also increase with similar trend. The increase of HREE values display variation from the top to $\sim 6.5 \mathrm{~m}$ (YB and $\mathrm{GCB}$ ) relative to the lower parts of the horizon (BRB, RB, and DRB). The chondrite-normalized REE distribution pattern of the diabase samples (as precursor of the bauxite horizon) displays a remarkable M-shaped (convex) tetrad effect in the third and fourth tetrads (Figure 10a). The Mshaped in both the third and fourth tetrads of chondrite-normalized REE distribution pattern is also observed in samples of YB part of the horizon (Figure 10b). The M-shaped of the normalized REE patterns was likely formed due to interaction of water-rock during formation of bauxite. 


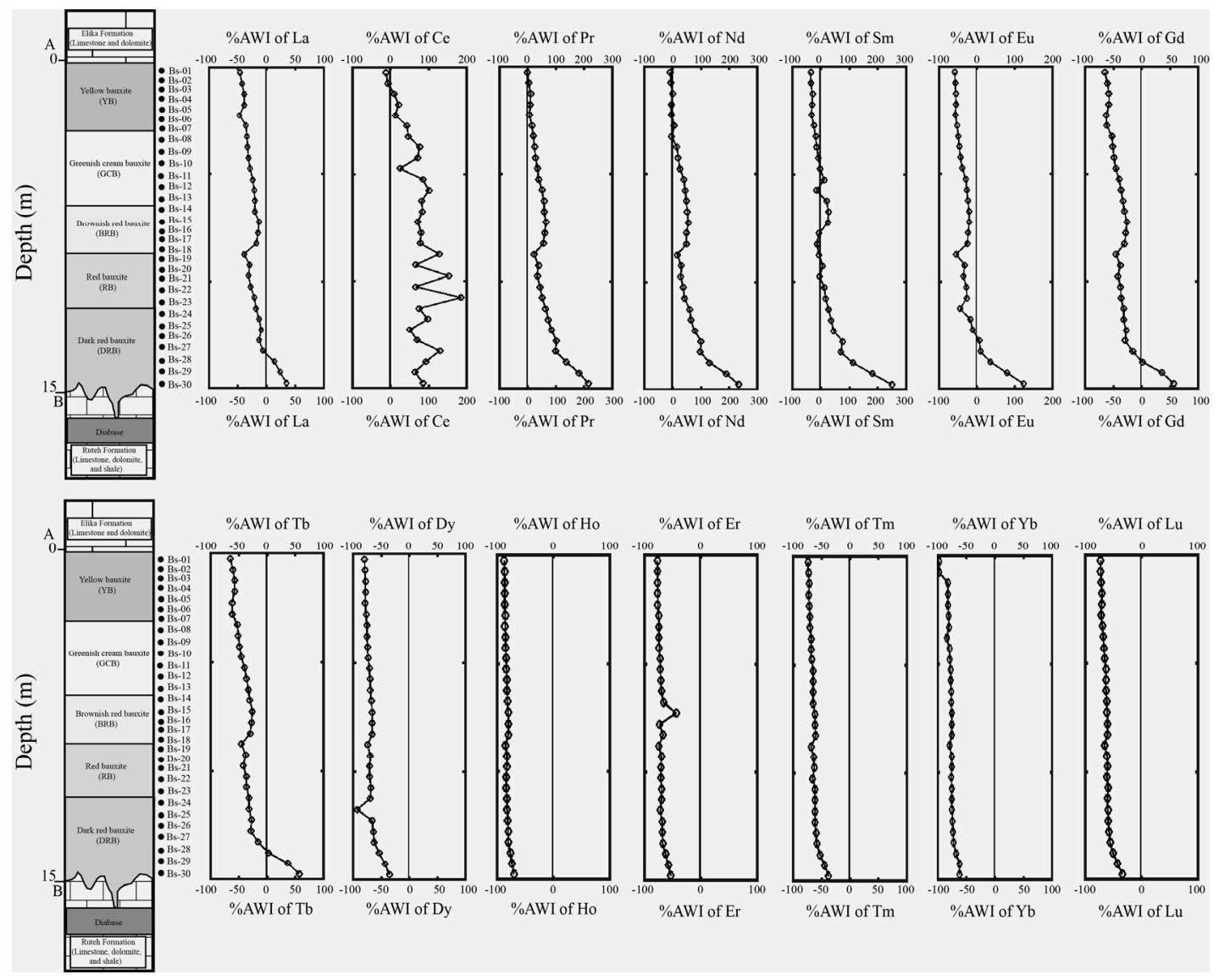

Fig. 8 Variation of AWI\% values of REE ( $\mathrm{La}$ to $\mathrm{Lu}$ ) in the bauxite ore samples of the studied horizon.

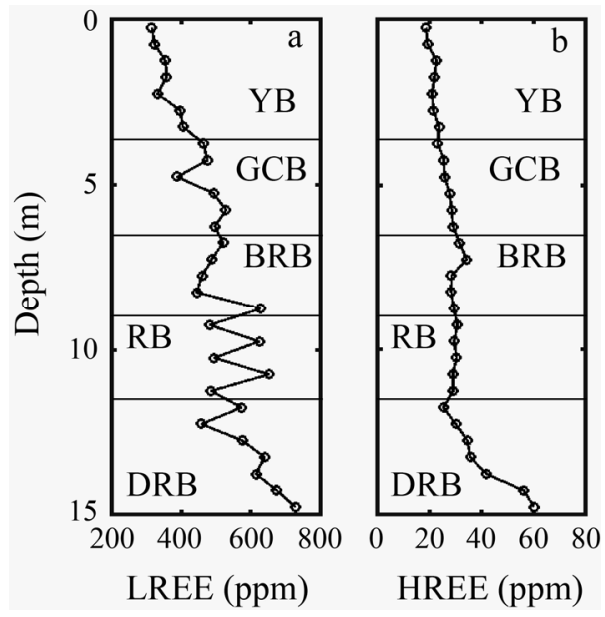

Fig. 9 Variations of (a) LREE (ppm) and (b) HREE (ppm) in different parts of the bauxite horizon at Kanisheeteh.
As illustrated in Figure 10c, similar form of tetrad (M-shaped) in chondrite-normalized REE distribution patterns also remains constant with no meaningful variation which is likely due to relatively stable conditions during bauxitization and/or weathering/alteration as well as diagenetic processes. The threshold of changes in deposition and lateral geochemical processes can be observed in simultaneous convex (M-shaped) and concave (Wshaped) tetrad effect curves. These features can be attributed to change in the bauxitization conditions and/or solution(s) during weathering and alteration processes (Censi et al., 2007; Monecke et al., 2007; Wu et al., 2011; Nardi et al., 2012). As shown in Figure 10d, the occurrence of both M- and W- shaped curves in the chondrite-normalized REE patterns of the BRB part of the horizon in this district may be owing to changes in depositional conditions. This is quite consistent with previous evidences such as higher $\mathrm{pH}$ of the solutions and increase of $\sum \mathrm{REE}$ content in lower parts of the horizon $(\mathrm{BRB}, \mathrm{RB}$ and DRB) as well. The conditions and/or solutions were likely stable in the lower parts of the horizon (e.g., $\mathrm{BRB}, \mathrm{RB}$ and $\mathrm{DRB}$ ) because of gradual increase in $\mathrm{pH}$ of the environment and consequently the convex (M-shaped) tetrad effect formed in the chondritenormalized REE distribution patterns due to waterrock interaction during bauxite formation. Therefore, 

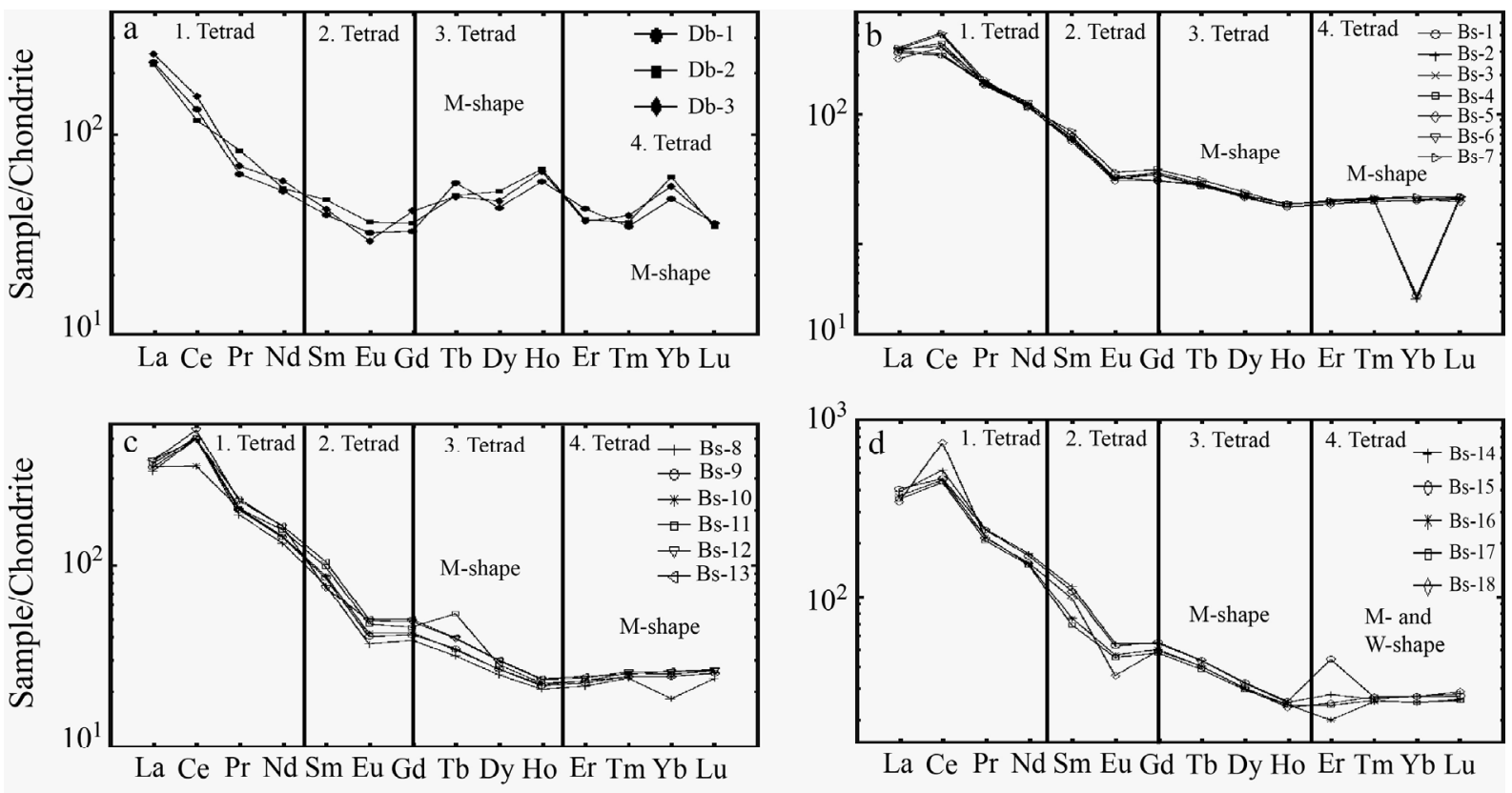

La Ce Pr Nd Sm Eu Gd Tb Dy Ho Er Tm Yb Lu
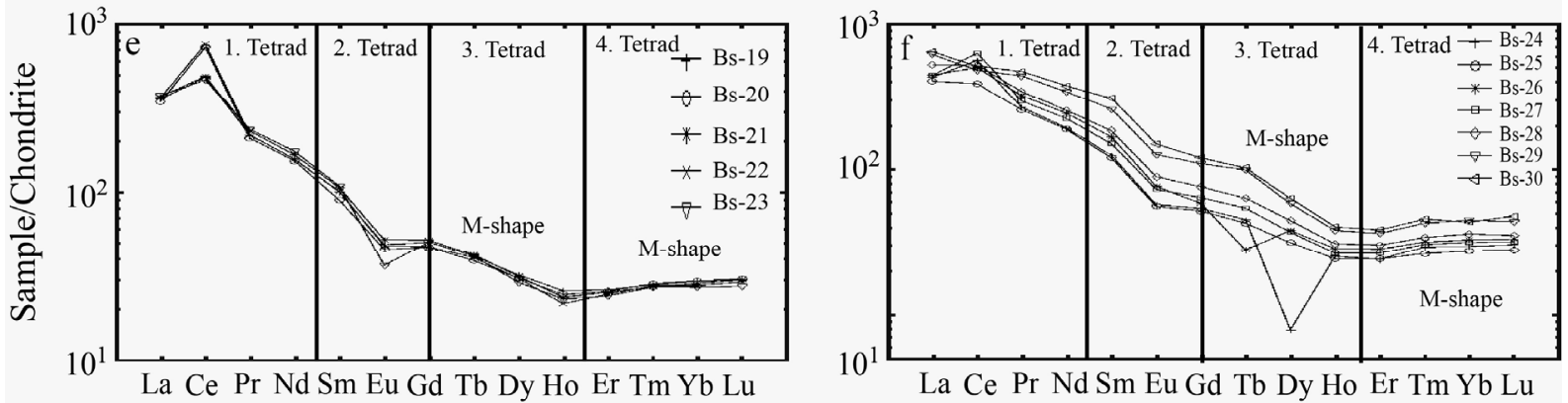

Fig. 10 Chondrite normalized REE distribution patterns of (a) diabase samples, (b) yellow bauxite ores (YB), (c) greenish cream bauxite ores (GCB), (d) brownish red bauxite ores (BRB), (e) red bauxite ores (RB), and (f) dark red bauxite ores (DRB).

it can be deduced that YB and GCB parts of the horizon were probably affected by low-pH acidic solutions. On the other hand, the lower parts of the horizon (BRB, RB and $\mathrm{DRB}$ ) experienced mostly alkaline conditions.

\subsection{CORRELATION BETWEEN T TETRAD EFFECT VALUES AND AWI\%}

The size of $\mathrm{T}_{4}$ tetrad effect values in all of the bauxite samples from different parts of the horizon with the computed values of AWI\% for the first, second, third, and fourth tetrads are illustrated in Figure 11, Figure 12, Figure 13, and Figure 14, respectively.

As shown in these figures, the REE distribution patterns versus $\mathrm{T}_{4}$ tetrad effect values in bauxite samples from the studied profile indicate two separate populations. The first group of the bauxite samples (belonging to YB and GCB parts) is characterized by a wide range of $\mathrm{T}_{4}$ tetrad effect values having negative correlation with AWI (\%) which reflects acidic environment. In contrast, the second population of bauxite samples (belonging to $\mathrm{BRB}, \mathrm{RB}$, and $\mathrm{DRB}$ parts) is marked by relatively narrow range of $T_{4}$ tetrad effect values and positive correlation with AWI (\%) of REE which reflects alkaline conditions. Therefore, it can be concluded that $\mathrm{T}_{4}$ tetrad effect values of the bauxite samples can be used as a good geochemical tool to investigate the geochemical processes.

\section{CONCLUSIONS}

The results of chemical analyses and calculated values for $\mathrm{Ce} / \mathrm{Ce}^{*}, \mathrm{Eu} / \mathrm{Eu}^{*}$, tetrad effect values, $\mathrm{Y} / \mathrm{Ho}$ ratios, and other geochemical parameters in the bauxite samples of the Kanisheeteh bauxite horizon indicate irregular patterns in chondrite-normalized REE distribution patterns. The occurrence of LTE in the third and fourth tetrads illustrates that REE distribution in this horizon was likely controlled by tetrad effect phenomenon. Based on the meaningful correlation between the sizes of $\mathrm{T}_{4}$ tetrad effect and $\mathrm{AWI} \%$ values, the conclusions are summarized as follows:

1. The distribution pattern of $\sum \mathrm{REE}$ from the top of the bauxite horizon to $\sim 6.5 \mathrm{~m}$ (YB and GCB) is 

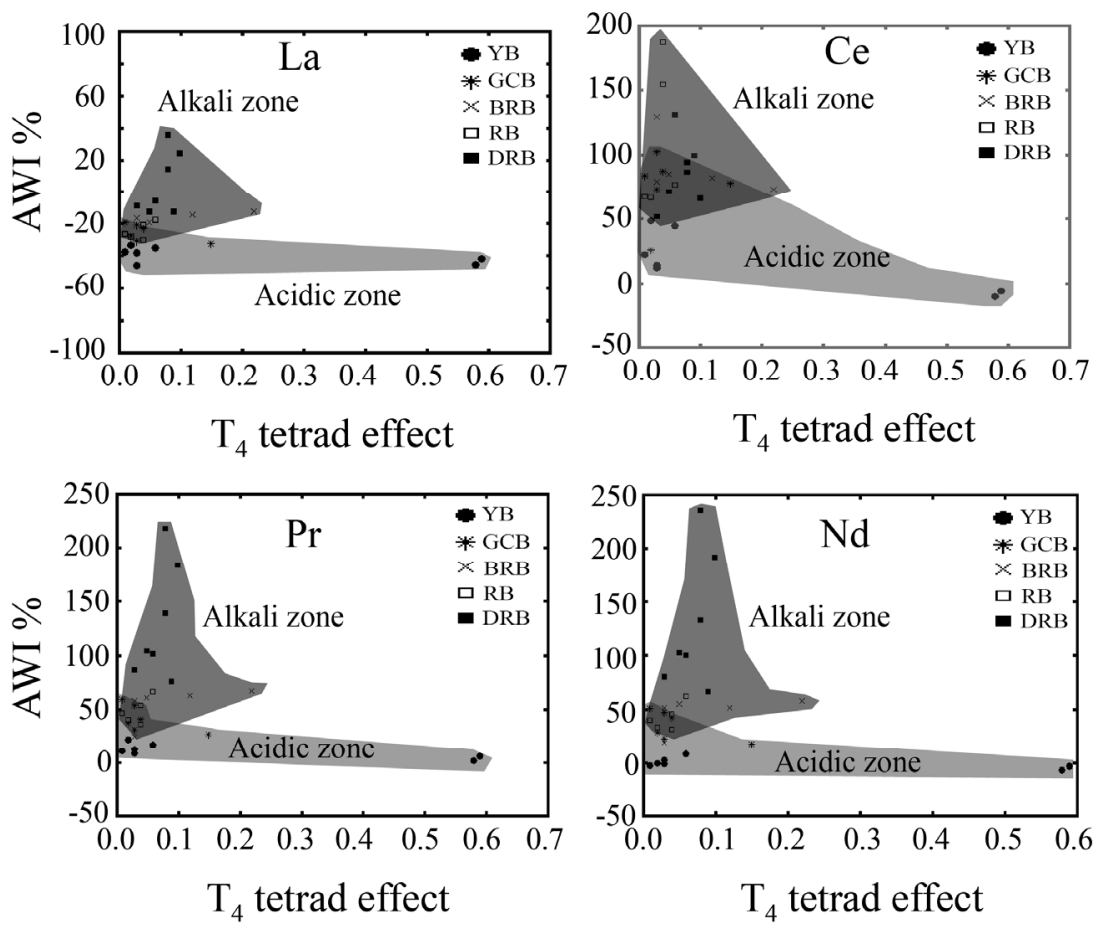

Fig. 11 Correlation between $\mathrm{T}_{4}$ tetrad effect and AWI\% values of the first tetrad group (La to $\mathrm{Nd}$ ).
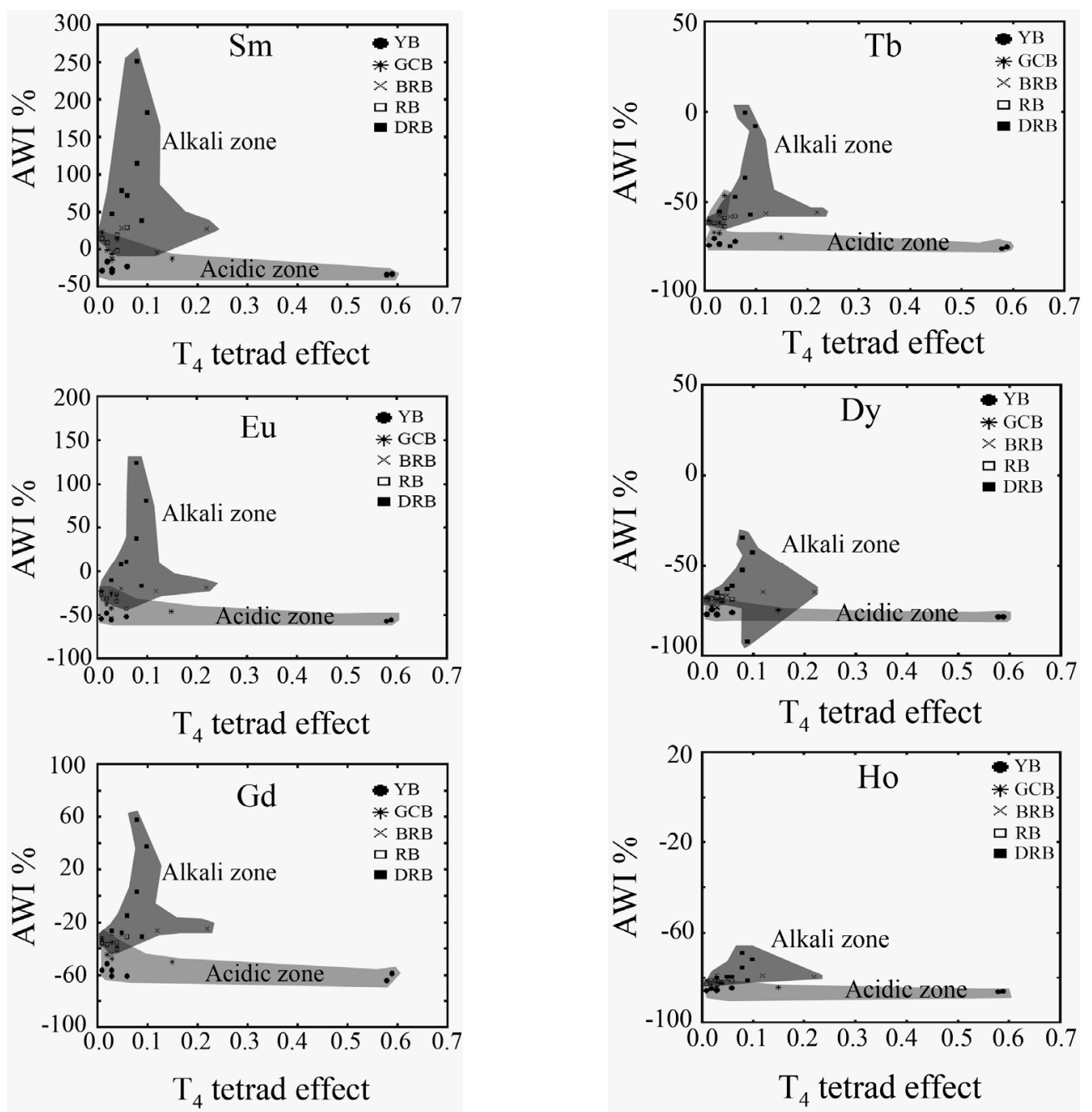

Fig. 12 Correlation between $\mathrm{T}_{4}$ tetrad effect and AWI\% values of the second tetrad group (Sm to $\mathrm{Gd}$ ).

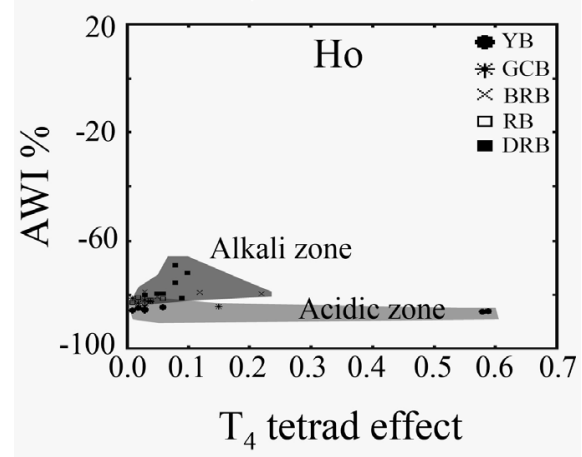

Fig. 13 Correlation between $\mathrm{T}_{4}$ tetrad effect and AWI\% values of the third tetrad group ( $\mathrm{Tb}$ to $\mathrm{Ho}$ ). $\mathrm{Gd}$ as a common element between the second and third tetrads is not here. 

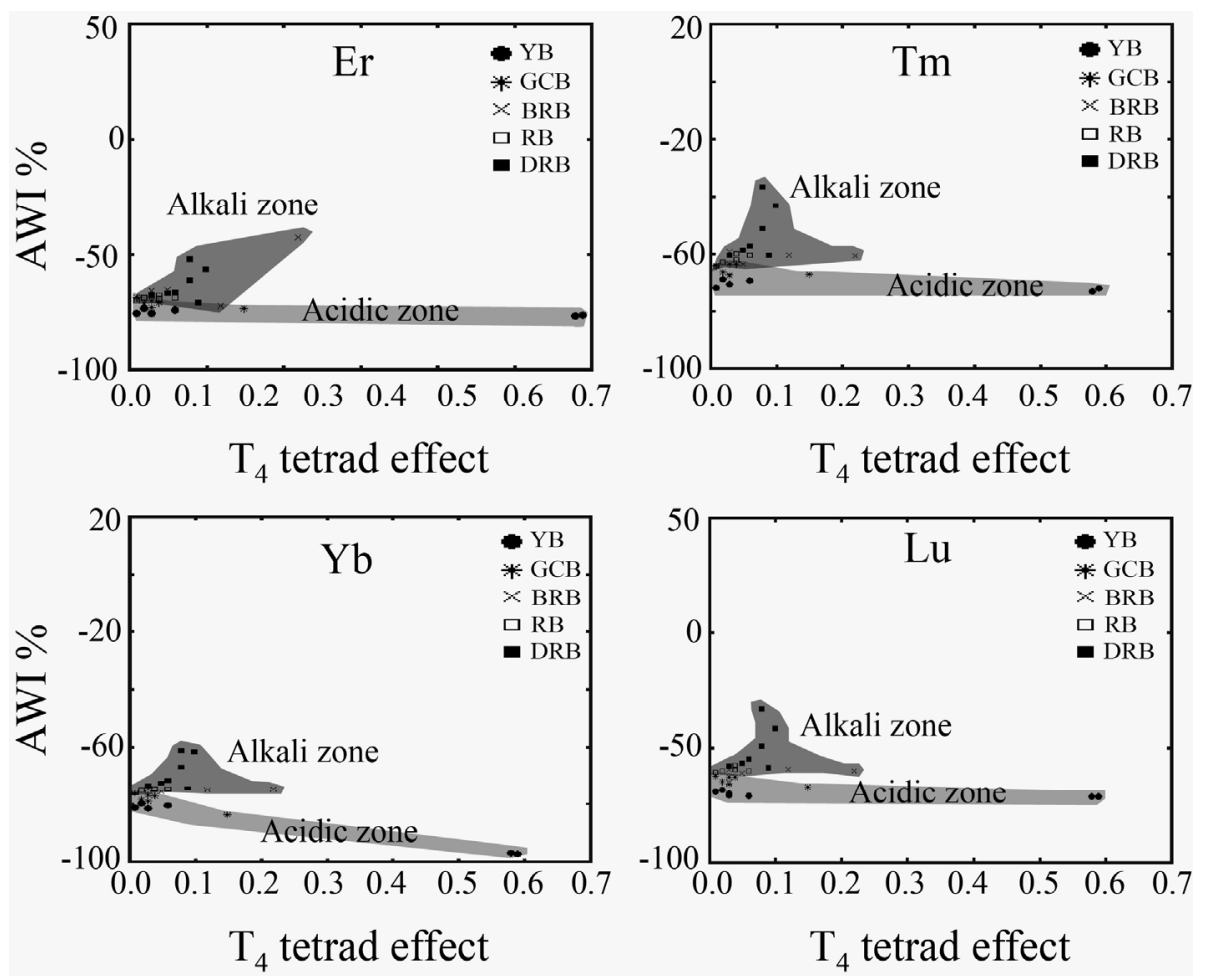

Fig. 14 Correlation between $\mathrm{T}_{4}$ tetrad effect and $\mathrm{AWI} \%$ values of the fourth tetrad group (Er to Lu).

relatively constant whereas, it differs in the lower parts of the horizon (BRB, RB, and DRB) where the amounts of REE increase. This feature can likely be related to $\mathrm{pH}$ increase of the solution responsible for bauxitization in this district.

2. Occurrence of both convex (M-shaped) and concave (W-shaped) curves in the chondritenormalized REE patterns indicate different depositional conditions during bauxitization of the parent rocks.

3. Based on the calculated $\mathrm{Ce} / \mathrm{Ce}^{*}$ values, it can be deduced that the $\mathrm{Ce}$ increment in the upper parts of the bauxite profile (YB and GCB) was due to the higher oxygen fugacity (relatively greater $\mathrm{Eh}$ ) by percolating the oxidizing meteoric waters/solutions. The Ce decrement in the lower parts of the horizon (BRB, RB, and DRB), however, may be owing to complexation of $\mathrm{Ce}^{4+}$ with carbonate ligands and thus its leaching during bauxitization processes.

4. The Y/Ho ratios of the bauxite samples display non-CHARAC behavior indicating presence of the tetrad effect feature in this system.

5. Based on the scatter diagrams of AWI\% for all REE versus $T_{4}$, a population is characterized by a wide range of $T_{4}$ values and negative correlation with the AWI\% (YB and GCB parts of the bauxite horizon) and the second one (BRB, RB, and DRB parts of the horizon) marked by relatively narrow range of $\mathrm{T}_{4}$ values and positive correlation with AWI\%. Therefore, it can be concluded that $T_{4}$ values of the bauxite samples can be utilized as a good geochemical tool to investigate the geochemical processes.

\section{ACKNOWLEDGMENTS}

This work was supported financially by the Research Bureau of Urmia University. We would like to express our thanks and gratitude to the authorities of this bureau. Our gratitude is further expressed to two anonymous reviewers for reviewing this manuscript and making critical comments and valuable suggestions, which have definitely improved the quality of this paper.

\section{REFERENCES}

Abedini, A. and Calagari, A.A.: 2013, Geochemical characteristics of Kanigorgeh ferruginous bauxite horizon, West-Azarbaidjan province, NW Iran. Periodico di Mineralogia, 82, 1-23. DOI: 10.2451/2013PM0001

Abedini, A. and Calagari, A.A.: 2014, REE geochemical characteristics of titanium-rich bauxites: the Permian Kanigorgeh horizon, NW Iran. Turkish Journal of Earth Sciences, 23, 513-532. DOI: $10.3906 /$ yer-1404-11

Abedini, A., Calagari, A.A. and Naseri, H.: 2016, Mineralization and REE geochemistry of hydrothermal quartz and calcite of Helmesi vein-type copper deposite, NW Iran. Neues Jahrbuch für Geologie und Paläontologie - Abhandlungen, 281, 123-134. DOI: 10.1127/njgpa/2016/0591

Abedini, A., Calagari, A.A. and Rezaei Azizi, M.: 2018a, The tetrad-effect in rare earth elements distribution patterns of titanium-rich bauxites: Evidence from the Kanigorgeh deposit, NW Iran. Journal of Geochemical Exploration, 186, 129-142. DOI: $10.1127 /$ njgpa/2017/0639

Abedini, A., Rezaei Azizi, M. and Calagari, A.A.: 2018b, Lanthanide tetrad effect in limestone: A tool to environment analysis of the Ruteh Formation, NW 
Iran. Acta Geodynamica et Geomaterialia 15, 229246. DOI: $10.13168 /$ AGG.2018.0017

Abedini, A., Rezaei Azizi, M. and Calagari, A.A.: 2018c, Lanthanide Tetrad Effect in Argillic Alteration: An Example from the Jizvan District, Northern Iran. Acta Geologica Sinica (English Edition) 92, 1468-1485. DOI: $10.1111 / 1755-6724.13638$

Abedini, A., Rezaei Azizi, M., Calagari, A.A., and Cheshmehsari, M.: 2017, Rare earth element geochemistry and tetrad effects of the Dalir phosphatic shales, northern Iran. Neues Jahrbuch für Geologie und Paläontologie -Abhandlungen, 286, 169-188. DOI: $10.1127 /$ njgpa/2017/0693

Akagi, T., Shabani, M.B. and Masuda, A.: 1993, Lanthanide tetrad effect in kimuraite $\left[\mathrm{CaY}_{2}\left(\mathrm{CO}_{3}\right)_{4} \cdot 6 \mathrm{H}_{2} \mathrm{O}\right]$ : Implication for an new geochemical index. Geochimica et Cosmochimica Acta, 57, 2899-2905. DOI: 10.1016/0016-7037(93)90397-F

Anders, E. and Grevesse, N.: 1989, Abundances of the elements: Meteoritic and solar. Geochimica et Cosmochimica Acta, 53, 187-214. DOI: 10.1016/0016-7037(89)90286-X

Bau, M. and Dulski, P.: 1996, Comparative study of yttrium and rare earth element behaviors in fluorine-rich hydrothermal fluids. Contributions to Mineralogy and Petrology 119, 213-223. DOI: 10.1007/BF00307282

Bau, M.: 1996, Controls on the fractionation of isovalent trace elements in magmatic and aqueous systems: evidence from $\mathrm{Y} / \mathrm{Ho}, \mathrm{Zr} / \mathrm{Hf}$, and lanthanide tetrad effect. Contributions to Mineralogy and Petrology, 123, 323-333. DOI: 10.1007/s004100050159

Braun, J.J., Viers, J., Dupre, M., Ndam, J. and Muller, J.J.: 1998, Solid liquid REE fractionation in the lateritic system of Goyoum, East Cameroon: The implication for the present dynamics of the soil covers of the humid tropical regions. Geochimica et Cosmochimica Acta, 62, 273-299.

DOI: $10.1016 / \mathrm{S} 0016-7037(97) 00344-\mathrm{X}$

Brimhall, G.H. and Dietrich, W.F.: 1987, Constitutive mass balance relations between chemical composition, volume, density, porosity and strain in metasomatic hydrothermal systems: Results on weathering pedogenesis. Geochimica et Cosmochimica Acta, 51, 567-587. DOI: 10.1016/0016-7037(87)90070-6

Broska, L., Gaab, A. and Kubis, M.: 2006, Tetrad effect in the western Carpathians granites and their petrological interpretation. Acta Mineralogica-Petrographia, Abstract Series 5, Szeged, 19.

Buccione, R., Mongelli, G., Sinisi, R. and Boni, M.: 2016, Relationship between geometric parameters and compositional data: A new approach to karst bauxites exploration. Journal of Geochemical Exploration, 169, 192-201. DOI: 10.1016/j.gexplo.2016.08.002

Calagari, A.A., Abedini, A., 2007. Geochemical investigations on Permo-Triassic bauxite deposit at Kanisheeteh, east of Bukan, Iran. Journal of Geochemical Exploration 94, 1-18. DOI: 10.1016/j.gexplo.2007.04.003

Cao, M.J., Zhou, Q.F., Qin, K.Z., Tang, D.M. and Evans, N.J.: 2013, The tetrad effect and geochemistry of apatite from the Altay Koktokay No. 3 pegmatite, Xinjiang, China: Implications for pegmatite petrogenesis. Mineralogy and Petrology, 107, 9851005. DOI: $10.1007 / \mathrm{s} 00710-013-0270-\mathrm{x}$

Censi, P., Sprovieri, M., Saiano, F., Di Geronimo, S.I., Larocca, D. and Placenti, F.: 2007, The behavior of
REE in Thailand's Mae Klong estuary: Suggestions from the $\mathrm{Y} / \mathrm{Ho}$ ratios and lanthanide tetrad effects. Estuarine Coastal and Shelf Science, 71, 569-579. DOI: 10.1016/j.ecss.2006.09.003

Chen, J., Wang, Q., Zhang, Q., Carranza, E.J.M. and Wang, J.: 2018, Mineralogical and geochemical investigations on the iron-rich gibbsitic bauxite in Yongjiang basin, SW China. Journal of Geochemical Exploration, 188, 413-426.

DOI: $10.1016 /$ j.gexplo.2018.02.007

Chen, Y.J. and Zhao, Y.C.: 1997, Geochemical characteristics and evolution of REE in the Early Precambrian sediments: Evidences from the southern margin of the North China Craton. Episodes, 20, 109116.

Chu, M.F., Wang, K.L., Griffin, W.L., Chung, S.L., O'reilly, S.Y., Pearson, N.J. and Iizuka, Y.: 2009, Apatite Composition: Tracing petrogenetic processes in Transhimalayan granitoids. Journal of Petrology, 50, 1829-1855. DOI: 10.1093/petrology/egp054

Constantopoulos, J.: 1988, Fluid inclusions and rare earth element geochemistry of fluorite from south-central Idaho. Economic Geology, 83, 626-636.

DOI: 10.2113/gsecongeo.83.3.626

Cunha, M.C.L., Nardi, L.V.S. and Müller, I.F.: 2012, Biogeochemistry of REE elements and tetrad effect in plants from volcanic soils in southernmost Brazil. Anais da Academia Brasileira de Ciências, 84, 911918. DOI: 10.1590/S0001-37652012005000069

Dai, A.B.: 1987, Coordination Chemistry. Science Press, Beijing, 870 pp., (in Chinese).

Duzgoren-Aydin, N.S., Aydin, A. and Malpas, J.: 2002, Reassessment of chemical weathering indices: Case study on pyroclastic rocks of Hong Kong. Engineering Geology, 63, 99-119.

DOI: 10.1016/S0013-7952(01)00073-4

Feng, J.L., Zhao, Z.H., Chen, F. and Hu, H.P.: 2014, Rare earth elements in sinters from the geothermal aters (hot springs) on the Tibetan Plateau, China. Journal of Volcanology and Geothermal Research, 287, 1-11. DOI: 10.1016/j.jvolgeores.2014.09.009

Fidelis, I. and Siekierski, S.: 1966, The regularities in stability constants of some rare earth complexes. Journal of Inorganic and Nuclear Chemistry, 28, 185188. DOI: $10.1016 / 0022-1902(66) 80243-9$

Gong, Q., Deng, J., Yang, L., Zhang, J., Wang, Q. and Zhang, G.: 2011, Behavior of major and trace elements during weathering of sericite-quartz schist. Journal of Asian Earth Sciences, 42, 1-13. DOI: 10.1016/j.jseaes.2011.03.003

Grant, J.A.: 1986, The isocon diagram-a simple solution to Gresens equation for metasomatic alteration. Economic Geology, 81, 1976-1982. DOI: 10.2113/gsecongeo.81.8.1976

Gresens, R.L.: 1967, Composition-volume relationships of metasomatism. Chemical Geology, 2, 47-55. DOI: 10.1016/0009-2541(67)90004-6

Haapala, I. and Lukkari, S.: 2005, Petrological and geochemical evolution of the Kymi stock, a topaz granite cupola within the Wiborg rapakivi batholith, Finland. Lithos, 80, 347-362. DOI: 10.1016/j.lithos.2004.05.012

Hannigan, R., Dorval, E. and Jones, C.: 2010, The rare earth element chemistry of estuarine surface sediments in the Chesapeake Bay. Chemical Geology, 272, 20-30. DOI: 10.1016/j.chemgeo.2010.01.009 
Hastie, A.R., Kerr, A.C., Mitchell, S.F. and Millar, I.L.: 2008, Geochemistry and petrogenesis of Cretaceous oceanic plateau lavas in eastern Jamaica. Lithos, 101, 323-343. DOI: 10.1016/j.lithos.2007.08.003

Henderson, P.: 1984, Rare Earth Element Geochemistry. Elsevier Scientific, Amsterdam.

Hou, Y.1., Zhong, Y.T., Xu, Y.G. and He, B.: 2017, The provenance of late Permian karstic bauxite deposits in SW China, constrained by the geochemistry of interbedded clastic rocks, and U-Pb-Hf-O isotopes of detrital zircons. Lithos, 278-281, 240-254. DOI: 10.1016/j.lithos.2017.01.013

Irber, W.: 1999, The lanthanide tetrad effect and its correlation with $\mathrm{K} / \mathrm{Rb}, \mathrm{Eu} / \mathrm{Eu}^{*}, \mathrm{Sr} / \mathrm{Eu}, \mathrm{Y} / \mathrm{Ho}$, and $\mathrm{Zr} / \mathrm{Hf}$ of evolving peraluminous granite suites. Geochimica et Cosmochimica Acta, 63, 489-508. DOI: 10.1016/S0016-7037(99)00027-7

Jahn, B.M., Wu, F., Capdevila, R., Martineau, F., Zhao, Z. and Wang, Y.: 2001, Highly evolved juvenile granites with tetrad REE patterns: the Woduhe and Baerzhe granites from the Great Xing'an Mountains in NE China. Lithos, 59, 171-198. DOI: 10.1016/S0024-4937(01)00066-4

Karadağ, M., Kupeli, S., Aryk, F., Ayhan, A., Zedef, V. and Doyen, A.: 2009, Rare earth element (REE) geochemistry and genetic implications of the Mortaş bauxite deposit (Seydişehir/Konya-Southern Turkey). Chemie der Erde-Geochemistry, 69, 143-159.

DOI: 10.1016/j.chemer.2008.04.005

Kawabe, I.: 1995, Tetrad effects and fine structures of REE abundance patterns of granitic and rhyolitic rocks: ICP-AES determinations of REE and Y in eight GSJ reference rocks. Geochemical Journal, 29, 213-230. DOI: 10.2343 /geochemj.29.213

Khosravi, M., Mongelli, G., Abedini, A. and Alipour, A.: 2017, The Darzi-Vali bauxite deposit, WestAzarbaidjan Province, Iran: Critical metals distribution and parental affinities. Journal of African Earth Sciences, 129, 960-972. DOI: 10.1016/j.jafrearsci.2017.02.024

Kraemer, D., Tepe, N., Pourret, O. and Bau, M.: 2016, Negative cerium anomalies in manganese (hydr)oxide precipitates due to cerium oxidation in the presence of dissolved siderophores. Geochimica et Cosmochimica Acta, 196, 197-208. DOI: 10.1016/j.gca.2016.09.018

Lee, S.G., Asahara, Y., Tanaka, T., Lee, S.R. and Lee, T.: 2013, Geochemical significance of the Rb-Sr, La-Ce and Sm-Nd isotope systems in A-type rocks with REE tetrad patterns and negative $\mathrm{Eu}$ and $\mathrm{Ce}$ anomalies: The Cretaceous Muamsa and Weolaksan granites, South Korea. Chemie Erde, 73, 75-88. DOI: $10.1016 /$ j.chemer.2012.11.008

Little, M.G. and Aeolus Lee, .C.T.: 2006, On the formation of an inverted weathering profile on Mount Kilimanjaro, Tanzania: buried paleosol or groundwater weathering?. Ghemica Geology, 235, 205-221. DOI: 10.1016/j.chemgeo.2006.06.012

Liu, X., Wang, Q., Zhang, Q., Zhang, Y. and Li, Y.: 2016, Genesis of REE minerals in the karstic bauxite in western Guangxi, China, and its constraints on the deposit formation conditions. Ore Geology Reviews, 75, 100-115. DOI: 10.1016/j.oregeorev.2015.12.015

Long,Y., Chi, G., Liu,J., Jin,Z. and Dai, T.: 2017, Trace and rare earth elements constraints on the sources of the Yunfeng paleokarstic bauxite deposit in the XiuwenQingzhen area, Guizhou, China. Ore Geology
Reviews, 91, 404-418.

DOI: 10.1016/j.oregeorev.2017.09.014

Ma, J., Wei, G., Xu, Y., Long, W. and Sun, W.: 2007, Mobilization and re-distribution of major and trace elements during extreme weathering of basalt in Hainan Island, South China. Geochimica et Cosmochimica Acta, 71, 3223-3237. DOI: 10.1016/j.gca.2007.03.035

MacLean, W.H. and Kranidiotis, P.: 1987, Immobile elements as monitors of mass transfer in hydrothermal alteration: Phelps Dodge massive sulfide deposit, Matagami, Quebec. Economic Geology, 82, 951-962. DOI: $10.2113 /$ gsecongeo.82.4.951

MacLean, W.H., Bonavia, F.F. and Sanna, G.: 1997 , Argillite debris converted to bauxite during karst weathering: Evidence from immobile element geochemistry at the Olmedo deposit, Sardinia. Mineralium Deposita, 32, 607-616. DOI: $10.1007 / \mathrm{s} 001260050126$

Masuda, A. and Ikeuchi, Y.: 1978, Lanthanide tetrad effect observed in marine environments. Geochemica Journal, 13, 19-22. DOI: 10.2343/geochemj.13.19

Mazumdar, A., Tanaka, K., Takahashi, T. and Kawabe, I.: 2003, Characteristics of rare earth element abundances in shallow marine continental platform carbonates of Late Neoproterozoic successions from India. Geochemica Journal, 37, 277-289. DOI: 10.2343 /geochemj.37.277

McLennan, S.M.: 1994, Rare earth element geochemistry and the "tetrad" effect. Geochimica et Cosmochimica Acta, 58, 2025-2033. DOI: $10.1016 / 0016-7037(94) 90282-8$

Minuzzi, O.R.R., Neto, A.C.B., Formoso, M.L.L., Andrade, S., Janasi, V.A. and Flores, J.A.: 2008, Rare earth element and yttrium geochemistry applied to the genetic study of cryolite ore at the Pitinga Mine (Amazon, Brazil). Anais da Academia Brasileira de Ciências, 80, 719-733. DOI: $10.1590 / \mathrm{S} 0001-37652008000400012$

Mondillo, N., Balassone, G., Boni, M. and Rollinson, G.: 2011, Karst bauxites in the Campania Apennines (southern Italy): A new approach. Periodico di Mineralogia, 80, 407-432. DOI: $10.2451 / 2011$ PM0028

Monecke, T., Dulski, P. and Kempe, U.: 2007, Origin of convex tetrads in rare earth element patterns of hydrothermally altered siliceous igneous rocks from the Zinnwald Sn-W deposit, Germany. Geochimica et Cosmochimica Acta, 71, 335-353.

DOI: 10.1016/j.gca.2006.09.010

Monecke, T., Kempe, U., Monecke, J., Sala, M. and Wolf, D.: 2002, Tetrad effect in rare earth element distribution patterns: A method of quantification with application to rock and mineral samples from graniterelated rare metal deposits. Geochimica et Cosmochimica Acta, 66, 1185-1196.

DOI: 10.1016/S0016-7037(01)00849-3

Monecke, T., Monecke, J., Mönch, W. and Kempe, U.: 2000, Mathematical analysis of rare earth element patterns of fluorites from the Ehrenfriedersdorf tin deposit, Germany: Evidence for a hydrothermal mixing process of lanthanides from two different sources. Mineraloy and Petrology, 70, 235-256. DOI: $10.1007 / \mathrm{s} 007100070$

Mongelli, G., Boni, M., Buccione, R. and Sinisi, R.: 2014, Geochemistry of the Apulian karst bauxites (southern 
Italy): Chemical fractionation and parental affinities. Ore Geology Reviews, 63, 9-21.

DOI: 10.1016/j.oregeorev.2014.04.012

Mongelli, G., Boni, M., Oggiano, G., Mameli, P., Sinisi, R., Buccione, R. and Mondillo, N.: 2017, Critical metals distribution in Tethyan karst bauxite: The cretaceous Italian ores. Ore Geology Reviews, 86, 526-536. DOI: 10.1016/j.oregeorev.2017.03.017

Mongelli, G., Buccione, R., Gueguen, E., Langone, A. and Sinisi, R.: 2016, Geochemistry of the apulian allochthonous karst bauxite, Southern Italy: Distribution of critical elements and constraints on Late Cretaceous Peri-Tethyan palaeogeography. Ore Geology Reviews, 77, 246-259.

DOI: 10.1016/j.oregeorev.2016.03.002

Nabavi, M.: 1976, A preface for geology of Iran. Geological Survey of Iran Publication (in Persian), 105 pp.

Nakamura, K., Morishita, T., Chang, Q., Neo, N. and Kumagai, H.: 2007, Discovery of lanthanide tetrad effect in an oceanic plagiogranite from an Ocean Core Complex at the Central Indian Ridge $25^{\circ} \mathrm{S}$. Geochemical Journal, 41, 135-140. DOI: $10.2343 /$ geochemj.41.135

Nardi, L.V.S., Formoso, M.L.L., Jarvis, K., Oliveira, L., Bastos Neto, A.C. and Fontana, E.: 2012, REE, Y, Nb, $\mathrm{U}$, and Th contents and tetrad effect in zircon from a magmatic-hydrothermal F-rich system of Sn-rare metalecryolite mineralized granites from the Pitinga Mine, Amazonia, Brazil. Journal of South American Earth Sciences, 33, 34-42.

DOI: 10.1016/j.jsames.2011.07.004

Ndjigui, P.D., Bilong, P., Bitom, D. and Dia, A.: 2008, Mobilization and redistribution of major and trace elements in two weathering profiles developed on serpentinites in the Lomié ultramafic complex, SouthEast Cameroon. Journal of African Earth Sciences, 50, 305-328. DOI: 10.1016/j.jafrearsci.2007.10.006

Nesbitt, H.W. and Markovics, G.: 1997, Weathering of granodioritic crust, long-term storage of elements in weathering profiles, and petrogenesis of siliciclastic sediments. Geochimica et Cosmochimica Acta, 61, 1653-1670. DOI: 10.1016/S0016-7037(97)00031-8

Nesbitt, H.W.: 1979, Mobility and fractionation of rare earth elements during weathering of a granodiorite. Nature, 279, 206-210. DOI: 10.1038/279206a0

Ng, C.W.W., Guan, P. and Shang, Y.J.: 2001, Weathering mechanisms and indices of the igneous rocks of Hong Kong. Quarterly Journal of Engineering Geology and Hydrogeology, 34, 133-151.

DOI: $10.1144 /$ qjegh.34.2.133

Peppard, D.F., Mason, G.W. and Lewey, S.: 1969, A tetrad effect in the liquid - liquid extraction ordering of lanthanide (III). Journal of Inorganic and Nuclear Chemistry, 31, 2271-2272.

DOI: 10.1016/0022-1902(69)90044-X

Peretyazhko, I.S., Savina, E.A., 2010. Tetrad effects in the rare earth element patterns of granitoid rocks as an indicator of fluoride silicate liquid immiscibility in magmatic systems. Petrology, 18, 514-543. DOI: $10.1134 / \mathrm{S} 086959111005005 \mathrm{X}$

Radusinovic, S., Jelenkovic, R., Pacevski, A., Simic, V., Bozovic, D., Holclajtner-Antunovic, I. and Zivotic, D.: 2017, Content and mode of occurrences of rare earth elements in the Zagrad karstic bauxite deposit (Niksic area, Montenegro). Ore Geology Reviews, 80, 406-428. DOI: 10.1016/j.oregeorev.2016.05.026
Rezaei Azizi, M., Abedini, A., Alipour, S. and Bagheri, H.: 2018a, REE geochemical characteristics and fluid inclusion studies of the Bagher-Abad fluorite deposit, Central Iran. Neues Jahrbuch für Mineralogie Abhandlungen, 195, 247-263.

DOI: $10.1127 /$ njma/2018/0124

Rezaei Azizi, M., Abedini, A., Alipour, S. and Bagheri, H.: 2018b, The Laal-Kan fluorite deposit, Zanjan Province, NW Iran: Constraints on REE geochemistry and fluid-inclusions. Arabian Journal of Geosciences, 11 (719), 1-16. DOI: 10.1007/s12517-018-4055-8

Rezaei Azizi, M., Abedini, A., Alipour, S., Niroomand, S., Sasmaz, A. and Talaei, B.: 2017, Rare earth element geochemistry and tetrad effects in fluorites: A case study from the Qahr-Abad deposit, Iran. Neues Jahrbuch für Geologie und Paläontologie Abhandlungen, 383, 255-273.

DOI: $10.1127 /$ njgpa/2017/0639

Riebe, C.S., Kiechner, J.W. and Finkel, R.C.: 2003, Longterm rates of chemical weathering and physical erosion from cosmogenic nuclides and geochemical mass balance. Geochimica et Cosmochimica Acta, 67, 4411-4427. DOI: 10.1016/S0016-7037(03)00382-X

Sasmaz A., Kryuchenko N., Zhovinsky E., Suyarko V., Konakci N. and Akgul B.: 2018, Major, trace and rare earth element (REE) geochemistry of different colored fluorites in the Bobrynets region, Ukraine. Ore Geology Reviews, 102, 338-350.

DOI: 10.1016/j.oregeorev.2018.09.014

Takahashi, Y., Yoshida, H., Sato, N., Hama, K., Yusa, Y. and Shimizu, H.: 2002, W- and M-type tetrad effects in REE patterns for water-rock systems in the Tono uranium deposit, central Japan. Chemical Geology, 184, 311-335. DOI: 10.1016/S0009-2541(01)00388-6

Torró, L., Proenza, J.A., Aiglsperger, T., Bover-Arnal, T., Villanova-de-Benavent, C., Rodríguez-García, D., Ramírez, A., Rodríguez, J., Mosquea, L.A. and Salas, R.: 2017, Geological, geochemical and mineralogical characteristics of REE-bearing Las Mercedes bauxite deposit, Dominican Republic. Ore Geology Reviews, 89, 114-131. DOI: 10.1016/j.oregeorev.2017.06.017

Wu, C.Z., Liu, S.H., Gu, L.X., Zhang, Z.Z. and Lei, R.X.: 2011, Formation mechanism of the lanthanide tetrad effect for a topaz and amazonite-bearing leucogranite pluton in eastern Xinjiang, NW China. Journal of Asian Earth Sciences, 42, 903-916. DOI: 10.1016/j.jseaes.2010.09.011

Yamamoto, K., Itoh, N., Matsumoto, T., Tanaka, T. and Adachi, M.: 2004, Geochemistry of Precambrian carbonate intercalated in pillows and its host basalt: implications for the REE composition of circa $3.4 \mathrm{Ga}$ seawater. Precambrian Research, 135, 331-344. DOI: 10.1016/j.precamres.2004.09.006

Yuste, A., Bauluz, B. and Mayayo, M.J.: 2017, Origin and geochemical evolution from ferrallitized clays to karst bauxite: An example from the Lower Cretaceous of NE Spain. Ore Geology Reviews, 84, 67-79. DOI: 10.1016/j.oregeorev.2016.12.025

Zhao, Z., Bao, Z. and Qiao, Y.: 2010, A peculiar composite M- and W-type REE tetrad effect: Evidence from the Shuiquangou alkaline syenite complex, Hebei Province, China. Chinese Science Bulletin, 55, 26842696. DOI: $10.1007 / \mathrm{s} 11434-010-3231-3$ 